NBER WORKING PAPER SERIES

\title{
ACCOUNTABILITY AND FLEXIBILITY IN PUBLIC SCHOOLS: EVIDENCE FROM BOSTON'S CHARTERS AND PILOTS
}

\author{
Atila Abdulkadiroglu \\ Joshua Angrist \\ Susan Dynarski \\ Thomas J. Kane \\ Parag Pathak \\ Working Paper 15549 \\ http://www.nber.org/papers/w15549 \\ NATIONAL BUREAU OF ECONOMIC RESEARCH \\ 1050 Massachusetts Avenue \\ Cambridge, MA 02138 \\ November 2009
}

The authors are grateful to the Boston Foundation for financial support and to Boston's charter schools, the Boston Public Schools, and Carrie Conaway, Mary Street, and the staff of the Massachusetts Department of Elementary and Secondary Education for data and assistance. Sarah Cohodes, Jon Fullerton and the staff of the Center for Education Policy Research at Harvard University played a critical role in this project. We also thank Bruno Ferman, Yuqiao Huang, Simone Schaner, Chris Walters, and Victor Vazquez for expert research assistance. We benefited from comments by Derek Neal and seminar participants at the Bank of Italy, the LSE, McGill, the New York Fed, UBC, UC Dublin, UCLA, UC Riverside, UIUC, ZEW, and the November 2009 New Directions in the Economic Analysis of Education Conference at the University of Chicago. Abdulkadiroglu acknowledges an NSF-CAREER award. Pathak thanks the Rappaport Institute for Greater Boston for research support. The views expressed herein are those of the author(s) and do not necessarily reflect the views of the National Bureau of Economic Research.

NBER working papers are circulated for discussion and comment purposes. They have not been peerreviewed or been subject to the review by the NBER Board of Directors that accompanies official NBER publications.

(C) 2009 by Atila Abdulkadiroglu, Joshua Angrist, Susan Dynarski, Thomas J. Kane, and Parag Pathak. All rights reserved. Short sections of text, not to exceed two paragraphs, may be quoted without explicit permission provided that full credit, including $\left({ }^{\circ}\right.$ notice, is given to the source. 
Accountability and Flexibility in Public Schools: Evidence from Boston's Charters and Pilots Atila Abdulkadiroglu, Joshua Angrist, Susan Dynarski, Thomas J. Kane, and Parag Pathak NBER Working Paper No. 15549

November 2009, Revised December 2009

JEL No. H52,I21,I28,J24

\begin{abstract}
$\underline{\text { ABSTRACT }}$
Charter schools are publicly funded but operate outside the regulatory framework and collective bargaining agreements characteristic of traditional public schools. In return for this freedom, charter schools are subject to heightened accountability. This paper estimates the impact of charter school attendance on student achievement using data from Boston, where charter schools enroll a growing share of students. We also evaluate an alternative to the charter model, Boston's pilot schools. These schools have some of the independence of charter schools, but operate within the school district, face little risk of closure, and are covered by many of same collective bargaining provisions as traditional public schools. Estimates using student assignment lotteries show large and significant test score gains for charter lottery winners in middle and high school. In contrast, lottery-based estimates for pilot schools are small and mostly insignificant. The large positive lottery-based estimates for charter schools are similar to estimates constructed using statistical controls in the same sample, but larger than those using statistical controls in a wider sample of schools. The latter are still substantial, however. The estimates for pilot schools are smaller and more variable than those for charters, with some significant negative effects.
\end{abstract}

\author{
Atila Abdulkadiroglu \\ Duke University \\ Department of Economics \\ Durham, NC 27708 \\ atila.abdulkadiroglu@duke.edu \\ Joshua Angrist \\ Department of Economics \\ MIT, E52-353 \\ 50 Memorial Drive \\ Cambridge, MA 02142-1347 \\ and NBER \\ angrist@mit.edu \\ Susan Dynarski \\ University of Michigan \\ Weill Hall \\ 735 South State Street \\ Ann Arbor, MI 48109-3091 \\ and NBER \\ dynarski@umich.edu
}

\author{
Thomas J. Kane \\ Harvard Graduate School of Education \\ Gutman Library, Room 455 \\ Appian Way \\ Cambridge, MA 02138 \\ and NBER \\ kaneto@gse.harvard.edu \\ Parag Pathak \\ Assistant Professor of Economics \\ E52-391C \\ MIT Department of Economics \\ Cambridge, MA 02142 \\ and NBER \\ ppathak@mit.edu
}




\section{Introduction}

Charter schools operate with considerably more independence than traditional public schools. They are free to structure their curriculum and school environment; for instance, many charter schools fit more instructional hours into a year by running longer school days and providing instruction on weekends and during the summer (Matthews 2009, Wilson 2008, Hoxby et al, 2009). Because few charter schools are unionized, they can hire and fire teachers and administrative staff without regard to the collectively bargained seniority and tenure provisions that constrain such decisions in most public schools. Although charter students made up only 2.9 percent of U.S. public school enrollment in 2008-2009, charter enrollment has grown rapidly and seems likely to accelerate in the near future (NAPCS 2009). The growth of charter schools is an important component of the contemporary education reform movement's pursuit of accountability and flexibility in public education.

Proponents see charter schools' freedom from regulation as a source of educational innovation, with the added benefit of providing a source of competition that may prompt innovation and improvement in the rest of the public system. At the same time, charter schools are controversial because, after a transition period in which the state provides subsidies, they receive a tuition payment for each enrolled student paid by students' home (or "sending") districts. In Massachusetts, the site of our study, tuition payments are determined largely by the average per-pupil expenditure in sending districts. Not surprisingly, therefore, public school districts are concerned about the revenue lost when their students enroll in charter schools.

The purpose of this paper is to assess the causal effects of charter school attendance and a closely related alternative, called pilot schools, on student achievement. Pilot schools arose in Boston as a union-supported alternative to charter schools. ${ }^{1}$ Boston's charter schools are legally constituted by the state as individual school districts and therefore operate independently of the Boston Public Schools (BPS). In contrast, Boston's pilot schools are legally part of the BPS district, and the extent to which they operate outside collective bargaining provisions is spelled out in school-specific election-to-work agreements signed by pilot faculty. In addition to these negotiated exemptions, pilot schools have generally greater flexibility and decision-making powers over school budgets, academic programs, and educational policies than do traditional BPS schools. This includes freedom with regard to policies related to student promotion, graduation, discipline, and attendance. ${ }^{2}$

\footnotetext{
${ }^{1}$ See Center for Collaborative Education (2006).

${ }^{2}$ See the Boston Teachers Union website (http://www.btu.org/leftnavbar/HP_PilotSchools.htm), which also notes: "Pilot schools do not have to purchase a variety of services provided by the central office, such as substitute teachers, textbook, SPED contracted services, and academic coaches. By not purchasing these services pilot schools 'save' , typically, $\$ 300$ to $\$ 400$ per year per student. They are allowed to retain these funds and purchase these services privately if they wish."
} 
In practice, pilot schools occupy a middle ground between charter schools and traditional public schools. Their teachers are part of the Boston Teachers Union (BTU), with their pay, benefits and working hours determined by the district-wide BTU contract. On the other hand, pilot schools can set their own policies with regard to curriculum, student promotion, and graduation. They also fit more instructional hours into a school year than traditional schools, but not as many as the charter schools. Accountability standards appear to bind less strictly for pilot schools than for charter schools: while nine Massachusetts charters have been lost, no pilot school has been closed.

The charter and pilot school models fit into a broader movement towards choice and decentralization in public education. Related policy experiments that have also been the subject of impact evaluations include vouchers (Rouse 1998; Angrist, Bettinger, Bloom, King and Kremer 2002), magnet schools (Cullen, Jacob, and Levitt 2006), and intra-district choice plans (Abdulkadiroğlu and Sönmez 2003; Hastings, Kane and Staiger 2008; Abdulkadiroğlu, Pathak and Roth 2009). Charter schools appear to be one of the most widely replicated members of this reform family.

The schools in our study are attended by students who would otherwise attend traditional Boston public schools. The Boston Public Schools (BPS) system serves a disproportionately Black and Hispanic student population. Like students in many urban schools, BPS students have lower test scores and lower rates of high school graduation and college attendance than students from nearby suburban districts. Boston's charter schools also serve a high proportion of Black students, even relative to the majority non-white BPS district. The effects of charter schools in urban populations are of special interest since any gains in this context might help reduce the black-white achievement gap.

The major empirical challenge in any study of alternative school models is selection bias. Students who attend charter and pilot schools differ in a number of ways from the general pool of public school students, a fact that biases naive comparisons. We can hope to eliminate some of this bias by controlling for student characteristics such as free lunch status, but the possibility of bias from unobserved variables such as motivation or family background remains. An important aspect of our study, therefore, is the use of student admissions lotteries to estimate causal effects. These lotteries, which admit applicants randomly at over-subscribed schools, are used to construct a quasiexperimental research design that should generate unbiased estimates of the causal effects of charter and pilot attendance.

A charter or pilot school contributes application cohorts to our lottery estimates when the school is over-subscribed and therefore runs a lottery, has complete lottery records, and, in the case of pilots, uses a lottery to select students. ${ }^{3}$ In addition, the charter schools in our lottery sample were all operating at the time we were collecting lottery data (closed charter schools have often been under-

\footnotetext{
${ }^{3}$ More precisely, a given school-year-grade cell contributes to the lottery analysis if entry at that point is oversubscribed and the resultant lottery records are available.
} 
subscribed). These selection criteria may have consequences for the external validity of our results. The over-subscription condition tilts our sample towards charter and pilot schools that parents find appealing, as does the requirement that schools still be open. From a policy perspective, however, this is an interesting set of schools. As it stands, Massachusetts currently limits both the number of charter schools and the proportion of a district's budget that can be lost due to charter enrollment. Were the supply of alternative school models allowed to freely vary, it seems reasonable to expect currently operating over-subscribed schools to expand and imitators to open similar schools.

The requirement that participating schools have complete lottery records also affects our selection of charter schools for the lottery sample. Specifically, the records requirement tilts the charter lottery sample towards schools that have archived lottery records. Massachusetts law does not require charter schools to retain their lottery data. The net impact of the record-keeping constraint is unclear. On one hand, poor record-keeping may be a sign of disorganization that spills over into teaching. On the other hand, lottery record-keeping may be a distraction that takes time and energy away from instructional activity. In some cases, lost records are also a result of bad luck and the fact that the preservation of lottery data is not a priority once the school admissions process is complete.

Finally, on the pilot side, not all schools use the centralized lottery system that is embedded in the BPS school assignment mechanism. Some pilot schools opt out of the BPS assignment mechanism and chose students by a combination of admissions testing or audition. Non-lottery pilots share this feature with Boston's elite exam schools (the most famous of which is the Boston Latin School). In contrast, over-subscribed charters must use lotteries to select students.

In an effort to gauge the generality of our lottery-based findings, we complement the quasiexperimental lottery analysis with an observational analysis of the full set of charter and pilot schools. The observational analysis controls for demographic and background characteristics as well as students' lagged test scores (for example, the elementary school scores of middle school students). This investigation produces estimates remarkably similar to the lottery-based estimates when carried out in the sample of charter schools that have lotteries, lending some credence to the observational analysis. At the same time, the observational analysis suggests that the charter schools in our sample are better than others in the sense of generating larger treatment effects. We therefore think of our (mostly positive) charter estimates as indicative of what a certain charter model can accomplish, rather than an overall charter-school treatment effect.

For pilot middle schools, the observational analysis also generates results that are broadly consistent with the lottery-based analysis, but the observational results for pilot high schools are more positive than the corresponding lottery-based estimates. This leaves a somewhat muddled picture. Across all designs and samples, however, the estimate effects of attending a pilot school are smaller than the 
corresponding charter estimates. In the subsample of pilot middle schools that serve only grades 6-8, lottery-based estimates of effects on middle school math scores are negative and significantly different from zero.

The next section describes Boston's charter and pilot schools in more detail and briefly discusses a few related studies and questions. Following that, Section III lays out our lottery-based estimation framework while Section IV discusses data and descriptive statistics. Section V presents the main lottery analysis. Section VI discusses the characteristics of the charter and pilot lottery compliers and reports results from models with ability interactions and possible peer effects. Section VII reports observational results from a broader sample, and compares these to the lottery estimates. The paper concludes in Section VIII.

\section{Background}

The 1993 Massachusetts Education Reform Act opened the door to charter schools in Massachusetts. Non-profit organizations, universities, teachers and parents can apply to the state's Board of Elementary and Secondary Education for a charter (there are no for-profit charter schools in Massachusetts). Massachusetts charter schools are generally managed by a board of trustees and are independent of local school committees. Like other public schools, charter schools charge no tuition and are funded mostly by sending districts according to formulas set by the state.

Massachusetts charter schools have a number of organizational features in common with charter schools in other states. First, they are typically outside local collective bargaining agreements. As a result, they have greater flexibility than traditional public schools when it comes to staffing, compensation, and scheduling. For example, the five Massachusetts charter schools studied by Merseth (2009), four of which appear in our lottery sample, have a longer school day and year than public schools. Many charter schools offer extensive tutoring during and after school. Moreover, teachers in charter schools need not hold an active state license to begin teaching, though they must pass the Massachusetts Test for Educator Licensure within the first year of employment.

Wilson (2008) describes seven Boston charters, six of which are in our lottery sample, as well as a charter school in Lynn, near Boston. Wilson identifies school practices prevalent at the schools in his sample. This collection of practices is sometimes said to characterize the "No Excuses" model, a term that probably originates with Thernstrom and Thernstom (2003). No Excuses schools are characterized by small size, frequent testing, a long school day and year, selective teacher hiring, and a strong student work ethic. Other features include an emphasis on discipline and comportment, teacher-led whole-class instruction, and the absence of computer-aided instruction. Merseth's (2009) detailed ac- 
count of the workings of five Boston-area charters, which she calls "high-performing schools," suggests they share these features.

The first two columns of Table 1 compare some of the statistically measurable differences between Boston charter schools and traditional (BPS) public schools. This table shows student-weighted averages of teacher characteristics and student-teacher ratios by school type. The student-teacher ratio is substantially lower in charter schools, and charter teachers are less likely to be licensed or to be "highly qualified" as defined by NCLB. The latter is likely a consequence of the relative inexperience of many charter school teachers, a fact documented in the age distribution data show in the table. ${ }^{4}$ As shown in column 7 of Table 1, the features that distinguish the full roster of Boston charter schools are shared by the schools in our lottery sample.

Massachusetts charter schools appear to face more stringent accountability requirements than non-charter public schools. The state Charter School Office reviews and makes recommendations on charter applications, reviews the performance of existing charter schools, and decides whether charters should be renewed. Charter schools are held accountable via annual reports, financial audits, and site visits, and are required to file for renewal every five years. Renewal applications must show that a school's academic program is successful, that the school is a viable organization, and that it has been faithful to its charter. Since 1994, the state has received a total of 350 charter applications and has granted 76. Eight of the 76 Massachusetts charters ever granted were surrendered or revoked as of Fall 2009 (Massachusetts Department of Elementary and Secondary Education, 2009b). A ninth (Uphams Corner Charter School) was revoked later in 2009. ${ }^{5}$

In the 2009-2010 school year, 26,384 Massachusetts students attended 62 operating charter schools, including 16 in Boston (Massachusetts Department of Elementary and Secondary Education 2009a). State law caps the number of charter schools at 72, and total enrollment at 30,034, so the statewide charter cap is not a constraint. However, a provision limiting local charter spending to nine percent of the district total generates binding or near-binding caps in specific districts, including Boston, where charter enrollment is already relatively high. The question of whether this local cap should be lifted is currently the subject of intense debate, fueled in part by the availability of federal stimulus money for states that facilitate new charters (Vaznis 2009).

Pilot schools were developed jointly by BPS and the Boston Teachers Union (BTU) as an alternative to both charter schools and traditional public schools. Pilot schools are created as the result

\footnotetext{
${ }^{4}$ The definition of highly qualified has varied over time, but typically this designation is awarded to teachers who have a bachelor's degree, full state certification or licensure, and have shown that they know the subject they teach (usually this requires some additional certification). Note that in Table 1, the denominators for the proportion licensed and the proportion highly qualified differ.

${ }^{5}$ Four of the eight charter losses through Fall 2009 occurred before school operations began. Two of the remaining four were revocations and two were non-renewals.
} 
of a planning process currently funded by the Boston Foundation, a private charity, with technical assistance from the Center for Collaborative Education, a local nonprofit organization that runs the Boston Pilot Schools Network. New schools may be granted pilot status but most are conversions from traditional BPS schools. Pilot school conversions must be authorized by a two-thirds vote of the BTU membership employed at the school and authorized by the BTU Pilot School Steering Committee. ${ }^{6}$

Like charter schools, pilot schools are answerable to independent governing boards. Also like charters, pilot schools determine their own budgets, staffing, curricula, and scheduling. Unlike charter schools, however, they remain part of the Boston school district and their teachers are BTU members covered by most contract provisions related to pay and seniority. Pilot school teachers have no job protection within schools but remain in the BPS system if they choose to move or are removed by the pilot school principal.

Pilot teachers sign an election-to-work agreement which spells out the extent to which union contract provisions apply. These agreements vary by school. ${ }^{7}$ Pilot schools are subject to external review, but the review process to date appears to be less extensive and structured than the external state charter reviews. No pilot school has been closed or converted back to a traditional public school. ${ }^{8}$ Pilot schools are open to all students in the BPS district and operate as part of the district. In the 2007-8 school year, 6,337 BPS students were enrolled in 20 pilot schools. Assignment to all elementary and middle pilot schools, and to two of the seven regular pilot high schools, is through the centralized BPS choice plan, which includes a lottery when schools are over-subscribed.

Pilot teachers have characteristics between those of traditional BPS schools and charter schools, as can be seen in columns 3 and 8 of Table 1. For example, pilot teachers are younger than traditional BPS teachers but not as young as charter teachers. Many pilot schools share with charter schools longer school days and years. But the BTU agreement covering pilot schools limits uncompensated overtime, as do school-specific election-to-work agreements. This is reflected in statistics on hours of instruction that we collected from the schools in our lottery sample. The official BPS school year is 180 days, with a little over six hours of instruction per day, for a total of 1,110 annual school hours. Annual school hours at pilot middle and high school hours run a little longer, but still under 1,200 hours/year. In contrast, the average charter middle school in our sample provides 1,500 hours of

\footnotetext{
${ }^{6}$ The pilot school model originated in Boston but other Massachusetts districts have begun to experiment with it. The Massachusetts Board of Elementary and Secondary Education recently adopted a Commonwealth Pilot School option for schools that otherwise would have been designated as underperforming under NCLB. Five Commonwealth Pilot Schools are now operating in Boston, Fitchburg, and Springfield. Versions of the pilot school model are also being tried in Los Angeles (Manzo, 2007).

${ }^{7}$ See http://www.ccebos.org/pilotschools/resources/index.html for sample agreements.

${ }^{8}$ For more on pilot structure, see http://www.ccebos.org/pilotschools/pilot_qa.doc and http://www.ccebos.org/pilotguides/. The current BTU contract allows for the creation of up to seven additional pilot schools. In 2007, two pilot conversions were voted down.
} 
instruction, while charter high schools provide about 1,400 hours. $^{9}$

\section{Related Studies and Questions}

A few recent studies use admissions lotteries to measure charter school achievement effects. These include Hoxby and Murarka (2009), which estimates charter effects in New York City (grades 3-8), Hoxby and Rockoff (2005), which estimates the effects of three Chicago charter schools, and Dobbie and Fryer (2009), which evaluates the effects of a charter middle and a charter elementary school located in the Harlem Children's Zone. All three studies report positive effects, though they vary by grade and subject. The achievement gains reported in Hoxby and Murarka (2009) and Hoxby and Rockoff (2005) are fairly modest, though Hoxby and Rockoff note problems with the Chicago charter lotteries that may invalidate some of their findings. The Dobbie and Fryer (2009) estimates for middle school math scores are the largest of the three, with impacts reaching almost half of a standard deviation per year in charter. Dobbie and Fryer also report IV estimates for an elementary school in the Harlem Children's Zone based on proximity to the Zone; these are imprecise. Farther afield, Clark (2009) uses a regression-discontinuity design to study the impact of attendance at Britain's grant-maintained schools, a charter-like model. Grant-maintained schools appear to have produced large achievement gains. ${ }^{10}$

A related study by Cullen, Jacob, and Levitt (2006) uses admissions lotteries to estimate the effect of attending Chicago magnet schools. Like Boston pilot schools, Chicago magnet schools are part of the local (Chicago Public Schools) district. Chicago magnet schools are also like pilot schools in that they offer special programs and enjoy a degree of autonomy while operating within the Chicago Public School district. Cullen, Jacob and Levitt find no evidence that winning a magnet lottery raises test scores or any other measure of academic performance, though magnet students are less likely to self-report being arrested or involved in disciplinary actions. Using administrative crime records, Deming (2009) similarly finds that adolescents lotteried into their first-choice public school in Charlotte-Mecklenburg are arrested less frequently and spend fewer days incarcerated, though they score no higher on standardized tests.

The question of whether innovations in school organization generate achievement gains is also part of a debate over whether schools alone can address large racial achievement gaps. Positions on this point sometimes translate into views about the social significance of charter schools in the Knowledge

\footnotetext{
${ }^{9}$ Data on hours of instruction at charter and pilot schools come from the individual schools' web sites.

${ }^{10}$ Charter evaluations that don't use lotteries have generally produced more mixed results. See, for example, Booker, Sass, Gill, and Zimmer (2008) for Chicago and Florida; Eberts and Hollenbeck (2002) for Michigan; Bifulco and Ladd (2006) for North Carolina; Booker, Gilpatric, Gronberg, and Jansen (2007) for Texas; Berends, Mendiburo, Nicotera (2008) for a Northwest Urban District; and CREDO (2009).
} 
is Power Program (KIPP). The students at KIPP schools are mostly from poor families and 95 percent are Black and Hispanic. Although there are no KIPP schools in our sample, most of the schools for which we have lottery data embrace the No Excuses model and serve a similar low-income, minority population.

The sense in which KIPP constitutes a marker for the role schools can play is clear from influential accounts on either side. In a study of the racial achievement gap, titled No Excuses, (Thernstrom and Thernstrom (2003, p. 43)) credit KIPP and similar No Excuses programs with impressive gains for low-income students:

Scattered across the American landscape are what some call "break-the-mold" schools high-poverty public schools with students who score well on statewide tests. There aren't many of them, and all are atypical within their own districts. Nevertheless, their record of success suggests that truly radical education innovation can change the lives of inner-city students, whatever their race or ethnicity.

An alternative view sees schools as only one part-arguably not the most important-in a broad struggle that requires social reform at many levels. Here is Rothstein (2004, p. 83), former New York Times education correspondent and an articulate spokesman for the systemic view:

. . there is nothing illogical about a belief that schools, if well-operated, can raise lower-class achievement without investing in health, social, early childhood, after-school, and summer programs. But while the belief is not illogical, it is implausible, and the many claims made about instructional heroes or methods that close that gap are, upon examination, unfounded.

Although our limited study cannot be definitive, we see the results as relevant for the evaluation of these opposing points of view. ${ }^{11}$

\section{Empirical Framework}

We're interested in the effects of charter or pilot school attendance on student achievement. Because the effects of attendance at different types of school seem likely to be an increasing function of the

\footnotetext{
${ }^{11}$ Researchers have also studied the effects of charter schools on traditional public schools. Examples include Bettinger (2005) and Booker, Gilpatric, Gronberg, and Jansen (2007). A related literature looks at the way parents make schooling choices (see, e.g., Hastings, Kane, and Staiger 2008; Hanushek, Kain, Rivkin, and Branch 2007; Jacob and Lefgren 2007). A few studies investigate general equilibrium effects of school choice on achievement (Hoxby 2000, 2007; Rothstein 2006, 2007).
} 
time spent in school, we model score effects as a function of years in pilot or years in charter. The causal relation of interest is captured using equations like this one for the scores, $y_{\text {igt }}$, of student $i$ testing in year $t$ in grade $g$ :

$$
y_{i g t}=\alpha_{t}+\beta_{g}+\sum_{j} \delta_{j} d_{i j}+\gamma^{\prime} X_{i}+\rho S_{i g t}+\epsilon_{i g t} .
$$

The variable $S_{i g t}$ is the years spent in a charter or pilot school as of the test date, counting any repeated grades, and counting time in all charter and pilot schools, not just the ones in our lottery samples. We also define a year to be a charter or pilot year if any portion of that year is spent in a charter or pilot school. The causal effect of $S_{i g t}$ is $\rho$. The terms $\alpha_{t}$ and $\beta_{g}$ are year-of-test and grade-of-test effects, while $X_{i}$ is a vector of demographic controls with coefficient $\gamma$, and $\epsilon_{i g t}$ is an error term that reflects random fluctuation in test scores. The dummies $d_{i j}$ are indicators for lottery-specific risk sets (indexed by $j$ ), described below.

If $S_{i g t}$ were randomly assigned, ordinary least squares (OLS) estimates of (1) would capture an average causal effect of years spent at a charter or pilot school. Because students and parents selectively chose schools, however, OLS estimates may be biased by correlation between school choice and unobserved variables related to ability, motivation, or family background. We therefore use an instrumental variables (IV) strategy that exploits the partial random assignment of $S_{i g t}$ in school-specific lotteries. Assuming the applicant lotteries are fair, students who win and lose a given lottery should have similar characteristics.

The first stage equations for IV estimation take the form:

$$
S_{i g t}=\lambda_{t}+\kappa_{g}+\sum_{j} \mu_{j} d_{i j}+\Gamma^{\prime} X_{i}+\pi Z_{i}+\eta_{i g t}
$$

where $\lambda_{t}$ and $\kappa_{g}$ are year-of-test and grade effects in the first stage. The first-stage effect is the coefficient, $\pi$, on the instrumental variable, $Z_{i}$. The charter instrument is a dummy for having been offered a seat at one of the schools in the applicants' charter risk set. The pilot instrument is a dummy for having a BPS lottery number below the highest number offered a spot in the pilot risk set.

For a given charter applicant, the charter risk set is the list of all lotteries to which the student applied in a given year and entry grade, among the lotteries included in our charter lottery sample. Students who did not apply to any of the charter schools in the lottery sample are not in any charter risk set and are therefore omitted from the IV analysis. The relevant sample of pilot applicants includes only those students who listed a pilot school first on their BPS assignment form (few students who did not do so end up in a pilot school). The pilot risk set is defined by the identity of this first-choice 
school and the applicant's walk-zone status. Charter and pilot risk sets also vary by grade of entry and year of application (the entry cohort). ${ }^{12}$

\section{Data and Descriptive Statistics}

The Massachusetts Students Information Management System (SIMS) contains information on all Massachusetts public school students' race, ethnicity, sex, reduced-price lunch status, special education status, English-language learner status, town of residence and current school. These data are collected in October and again at the end of the school year. We worked with SIMS files for the 2001-2002 through 2006-2007 school years. The SIMS data were used to determine how many years students spent in a charter, pilot or traditional BPS school. A student observed at any time during a school year in a charter or pilot school was classified as a charter or pilot student for that year. To construct an analysis file, we used student identifiers to merge SIMS demographic and school history data with test scores from the Massachusetts Comprehensive Assessment System (MCAS) database, again for the 2001-2002 through 2007-2008 school years. The MCAS database contains raw scores for math, English language arts (ELA), and writing. MCAS is administered each spring, typically in grades 3-8 and 10. For the purposes of our analysis, scores were standardized by subject, grade, and year to have mean zero and unit variance in the population of students attending Boston schools.

\section{Lottery Procedures and Sample Coverage}

Each charter school collects applications and holds its own lottery in years the school is over-subscribed. Siblings of students already attending the school are guaranteed a seat, as are students continuing on from earlier grades. Students can apply to as many charter schools as they like; the lotteries are statistically and administratively independent. Students may therefore be accepted or wait-listed at more than one school. When admitted students decline, slots open up for additional offers farther down the lottery list. Thus, some students may be offered spots immediately, while others may be offered seats closer to the beginning of the school year. Charter school lottery records were matched to MCAS and SIMS data using applicants' names and year and grade of application. ${ }^{13}$

\footnotetext{
${ }^{12}$ The relevant risk set for students in the pilot lottery is based on the BPS assignment mechanism. Among first-choice applicants to a given pilot school, admission priority is randomly assigned, with lotteries run separately for students who live inside and outside the school's walk-zone. In the pilot analysis, the risk set is therefore specified as the interaction of the four variables indicating the student's first-choice pilot school, walk-zone status for that school, and the year and grade of application.

${ }^{13}$ Gender, race, town of residence, and date of birth were used to resolve ambiguities. We matched 96.5 percent of charter applicants at the middle school level (97.3 percent of those admitted and 94.8 percent of those not admitted) and 92.2 percent of applicants at the high school level (92 percent of those admitted and 92.9 percent of those not admitted).
} 
We asked all operating charter schools in Boston for current and past lottery records. The set of charter schools and applicant years included in the lottery sample is detailed in Table A1. Of the four charter schools with elementary grades, one had lottery records for a period that we could use, but these are for 6th grade entrants and hence contribute to the middle school sample (this school added elementary grades only in 2006). Of the 11 charter schools that enroll middle school students, five contribute to the lottery analysis. Two of the omitted middle schools closed before or while our study was under way (one was under-subscribed), so that charter middle school coverage consists of 5 out of 9 currently operating schools. Two omitted middle schools admit primarily from their own elementary grades. In such cases, we were unable to recover lottery records because the entry date precedes the outcome dates by at least seven years.

Of the eight charter schools that enroll regular (non-alternative) high school students, four contribute to the lottery analysis. Two of the omitted high schools closed before or during our study (one was under-subscribed) and two admit students at younger grades and are included in the middle school sample. Our charter high school sample therefore includes all four of Boston's currently operating regular 9-12 charter high schools.

Students apply to pilot schools as part of the regular BPS assignment mechanism. BPS parents submit a rank order list of at least three schools in January to obtain a seat at a new school in September. At each school, admission priority is determined in part by whether the applicant is a continuing student who is guaranteed admission, currently has a sibling at the school, or lives in the school's walk zone. Within these priority groups, students are selected using an ordering determined by the BPS lottery number. The choice mechanism tries to assign as many students as possible to their top choice, using coarse priority rankings and lottery numbers when there are more applicants than capacity. ${ }^{14}$ This produces a system that induces random assignment (albeit with varying probabilities), conditional on priority groups such as sibling and walk-zone status.

Students were classified as pilot applicants if they listed a pilot school as their first choice. Because most pilot schools are oversubscribed, students who rank a pilot school as a second or lower choice are unlikely to be assigned to a pilot. The BPS assignment mechanism runs in multiple rounds but we use information only from the first round. Data on parents' choices and BPS lottery numbers came from the BPS applications data base. These data were matched to our merged MCAS-SIMS analysis file using state identifiers.

All elementary and middle school pilots use the BPS assignment mechanism and lottery, but only two pilot high schools do. Four others use school-specific admissions criteria, such as musical auditions, to select their students. One is a 6-12 school that was not over-subscribed. Of the seven pilot schools

Additional information related to the construction of analysis files appears in the data appendix.

${ }^{14}$ For details, see Abdulkadiroğlu and Sönmez (2003) and Abdulkadiroğlu, Pathak, Roth and Sönmez (2006). 
that enroll elementary school students, five were over-subscribed and contribute to the lottery sample. Of seven pilot middle schools admitting 6th graders, six were over-subscribed and contribute to the lottery sample. Of the four K-8 pilot schools, our lottery middle school sample includes kindergarten applicants from three (the kindergarten entry grade is known as K2, the year after preschool, K1). One K-8 pilot school opened too late to contribute middle school test scores by K2 applicants.

One of the high schools in our charter lottery sample (Health Careers Academy or HCA) is what is known as a Horace Mann charter school. HCA is the only Horace Mann charter that serves the regular 9-12 population in Boston. ${ }^{15} \mathrm{HCA}$ is unusual in that it began as a pilot school in 1995, but converted to a Horace Mann charter school in 1997.

Like pilot schools, a Horace Mann charter school's employees are members of the BTU bargaining unit and Horace Mann charters are established with the approval of BPS and the BTU. Otherwise, however, they operate like other charter schools (called Commonwealth charters). In particular, HCA is subject to state (as opposed to district) supervision, and must submit to the same type of five-year review for charter renewal. HCA operates in rented space on the Northeastern University campus, does not use BPS facilities, and is funded like other charter schools. ${ }^{16}$ The elect-to-work agreements at HCA also appear to allow for more unpaid overtime than those at pilot schools. Because HCA has features in common with pilot schools, however, we look briefly at the implications of a reclassification of HCA as a pilot school in our sensitivity analysis.

\section{Student Characteristics and Covariate Balance}

Table 2 reports descriptive statistics for students at Boston's traditional schools, charter schools, and pilot schools, as well as a separate breakout for those included in the charter and pilot lottery samples. The racial and ethnic composition of the student bodies attending pilot elementary and middle schools is similar to that at traditional BPS schools: around 45 percent Black and 30 percent Hispanic. In

\footnotetext{
${ }^{15}$ The other Boston-area Horace Mann charter school, called Boston Day and Evening Academy, is an alternative school; it serves students aged 16-22 who are overage for grade level or have dropped out.

${ }^{16}$ The Massachusetts Department of Elementary and Secondary Education describes the two charter models as follows: A charter school is a public school that is governed by a board of trustees and operates independently of any school committee under a five year charter granted by the Board of Elementary and Secondary Education (Board). It has the freedom to organize around a core mission, curriculum, theme, and/or teaching method and to control its own budget and hire (and fire) teachers and staff. In return for this freedom, a charter school must attract students and produce positive results within five years or its charter will not be renewed. There are two types of charter schools, Commonwealth charter schools and Horace Mann charter schools. They operate under the same set of rules as described above, with the following exceptions. First, a Horace Mann charter school must have its charter approved by the local school committee and the local teacher's union in addition to the Board. Second, to the extent provided by their charters, Horace Mann charter schools may be exempt from certain provisions in local collective bargaining agreements. Third, employees of a Horace Mann charter school remain members of the local collective bargaining unit; continue to accrue seniority; and receive, at a minimum, the salary and benefits established by the local collective bargaining agreement. See also http://www.doemass.org/charter/qanda.doc.
} 
contrast, charter schools have a higher proportion of Black students (about 70 percent) and a lower proportion of Hispanic students (about 20 percent). Differences in racial make-up across school types are similar at the high school level.

Roughly 85 percent of students at traditional Boston schools are eligible for free or reduced-price lunch, a measure of poverty status. Charter students are not as poor; about 70 percent fall into this category. The pilot school student body occupies a middle ground, with more poor students than the charter schools but fewer than the traditional schools. Relatively few English learners (also known as limited English proficiency or LEP students) attend charter schools. For example, only seven percent of charter middle schools students are LEP, while the traditional Boston population is 22 percent LEP (pilot schools are close at 21 percent). Charter schools also enroll fewer special education students than traditional schools and pilot schools. Girls are over-represented at charter schools and, to a lesser extent, at pilot schools; this is particularly striking at the high school level, where nearly 60 percent of charter school students are female, compared to 52 percent at the pilot schools and 50 percent at traditional schools. Importantly, however, the demographic make-up of the charter and pilot lottery samples, described in columns 6 and 7 of Table 2, is similar to that of the total charter and pilot samples.

Table 2 also reports pre-treatment test scores - measured in elementary school for the middle school sample and in middle school for the high school sample. We think of these lagged score variables as baseline ability measures. For middle school students, baseline scores come from tests taken in fourth grade while for high school students baseline scores come from tests taken in eighth grade. There are no baseline scores for elementary school students, since MCAS testing starts in third grade. At the middle school level, pilot school students have somewhat lower baseline scores than students at traditional schools, while baseline scores of the charter students are closer to those for students in traditional BPS schools. At the high school level, charter school students have higher baseline scores, averaging about 0.4 standard deviations above those of students in traditional schools and a tenth of a standard deviation above those of students attending pilot schools. Among charter school students applying to lotteried middle schools, there is a baseline advantage of about 0.2 standard deviations.

As a measure of lottery quality, Table 3 reports covariate differences between winners and losers. The numbers reported in the table are regression-adjusted differences by win/loss status, where a win means students were offered a spot in a charter or pilot school in the relevant risk set. The only covariates in the regression are dummies for risk sets (year of application and the set of schools applied to for charters; first-choice school, year of application, and walk zone status for pilots). Conditional on these covariates, lottery wins should be randomly assigned.

With a few exceptions, the differences in Table 3 are small and statistically insignificant. Among 
middle school applicants, charter lottery winners have baseline math scores a tenth of a standard deviation above losers' scores; at the high school level, winners are two percentage points more likely to be Asian and two percentage points more likely to be English learners. These differences are only marginally significant and could be due to chance. Among elementary pilot schools applicants, lottery winners are eight percentage points less likely to be eligible for a subsidized lunch, while at the high school level, they are six percentage points more likely to be eligible. Again, these and the other scattered marginally significant contrasts in the table seem likely to be chance findings. This conclusion is reinforced by the $\mathrm{F}$ statistics at the bottom of each column, which test the joint hypothesis that all differences in baseline test scores and background characteristics in the column are zero. Only two of these are close to a 0.05 p-value.

\section{Lottery-Based Estimates}

\section{Charter School Effects}

Charter middle school applicants who were offered a spot at one of the schools to which they applied spent about a year longer attending a charter school than applicants who were not offered a spot. This difference, which is shown in column 1 of Table 4 (labeled "first stage"), is measured as of the MCAS test date. The first stage is smaller than the three-year span of middle school because about a fifth of lottery winners never attend a charter school, while some lottery losers end up in charter school later, either because they enter the admissions lottery in a future year, gain sibling preference when a sibling wins the lottery, or move off a wait list after the offers coded by our instrument. In addition, some tests were taken as earlier as one year into middle school (the MCAS tests math and ELA proficiency in every middle school grade).

Middle-school students who win the charter lottery score almost $0.2 \sigma$ higher on ELA and $0.4 \sigma$ higher in math, as shown in column 2 of Table 4 (labeled "reduced form"). The 2SLS estimate of the effect of an additional year in a charter school is the ratio of the reduced-form estimates to the first-stage coefficients. Since the first stage coefficients are close to one, the 2SLS estimates (reported in column 3) are similar to the reduced form estimates, though their interpretation differs. When estimated without demographic controls, the 2SLS estimates imply that ELA scores increase by about $0.2 \sigma$ for each year in a charter, while the per-year math effect is $0.4 \sigma$. These estimates are reasonably precise, with standard errors around $0.06-0.08$, showing that our research design has the power to detect more modest effects as well. The addition of demographic controls changes this result little, as can be seen in column 4 .

Although the reduced form effects on high school ELA and math scores are smaller than the 
corresponding reduced form effects in middle school, the high school first stage is also smaller. As a consequence, the ELA and math score gains generated by time spent in charter high schools are estimated to be similar to the corresponding 2SLS estimates for middle school. High school students also take a writing test; here the 2SLS estimates show gains of $0.17 \sigma-0.28 \sigma$. As with the results for middle school, the addition of demographic controls leaves the estimates largely unchanged.

\section{Pilot School Effects}

Our lottery-based analysis of pilot effects looks at elementary-grade outcomes as well as test scores from middle and high school. The impact of a pilot school offer on time spent in elementary school is almost three years, as can be seen at the top of column 5 in Table 4. The relatively large elementary-level pilot first stage is driven by the fact that elementary school applicants apply to enter in kindergarten, while they are not tested until third or fourth grade. The reduced form effect of a pilot school offer on elementary school applicants is a little under $0.2 \sigma$, but this translates into a much smaller per-year effect of $0.06 \sigma-0.07 \sigma$, reported in column 7 for models without demographic controls.

The estimated effect of a pilot offer on time spent in high school is similar to the corresponding first stage for charter applicants, while the pilot middle school first stage is somewhat larger. On the other hand, the estimated effects on ELA and math scores-both reduced form and 2SLS-are much smaller (one is negative) and not significantly different from zero. Here too, it's worth pointing out that the standard errors are of a size that modest effects, say on the order of $0.1 \sigma$, would be detectable in middle school, though the high school design has less power. The only significant post-elementary pilot school estimate is for one of the writing scores (This is $0.18 \sigma$, a marginally significant result). Finally, as with the charter lottery results, the estimates using pilot school lotteries are similar with and without demographic controls. The pilot school estimates with demographic controls appear in column 8.

\section{Robustness and Magnitudes}

The strong charter school effects on middle school scores reported in Table 4 are readily apparent in a visual representation of IV estimates based on a version of equations (1) and (2). Averaging equation (1) conditional on treatment status and risk set (and dropping covariates), we have

$$
E\left[y_{i g t} \mid d_{i j}=1, Z_{i}\right]=\alpha_{t}+\beta_{g}+\delta_{j}+\rho E\left[S_{i g t} \mid d_{i j}, Z_{i}\right]
$$


Differencing (3) by offer status within risk sets, this becomes

$$
E\left[y_{i g t} \mid d_{i j}=1, Z_{i}=1\right]-E\left[y_{i g t} \mid d_{i j}, Z_{i}=0\right]=\rho\left(E\left[S_{i g t} \mid d_{i j}, Z_{i}=1\right]-E\left[S_{i g t} \mid d_{i j}, Z_{i}=0\right]\right) .
$$

In other words, the slope of the line linking offer-status differences in test scores within risk sets to the corresponding offer-status differences in average years at a charter or pilot school should be the causal effect of interest, $\rho$.

The empirical counterpart of equation (4) for charter applicants' middle school math scores appears in Panel A of Figure 1. The unit of observation here is a charter risk set. The regression line fits the scatterplot well, with no highly influential or outlying risk sets. The slope of the line in the figure is 0.44 when weighted by the size of risk sets. The corresponding 2SLS estimate of $\rho$ using a full set of offer $\times$ risk set dummies as instruments in a model without out covariates is identical. ${ }^{17}$ In contrast, the analogous plot for pilot schools, plotted in Panel B, shows a flatter line, with a slope of -0.045 . The pilot $\mathrm{x}$-axis has a wider range than that for charters because some of the pilot risk sets are small, and because applicants to pilot K-8 schools may spend a longer time in a pilot school than applicants to grade $6-8$ schools. But omitting the small risk sets and outlying first stage values leaves the weak negative relation captured in the figure essentially unchanged.

Most of the lottery results shown in Table 4 are insensitive to the inclusion of controls for applicants' baseline test scores. This is documented in Table 5, which reports results with additional controls and alternative samples. For reference, Table 5 also repeats the 2SLS estimates with demographic controls from Table 4 (these regressions also include dummies for year of test, year of birth, and risk sets). Baseline test scores are available for students who have taken the MCAS before applying to the lottery; the sample used to construct pilot lottery estimates with baseline score controls therefore omits elementary school students and K2 applicants to pilot K-8 middle schools.

The addition of baseline score controls has almost no effect on the charter lottery estimates, a result documented in column 2 of Table 5. On the other hand, the pilot lottery estimates for middle school math scores turn negative and at least marginally significant with baseline score controls, as can be seen in column 6 . There is little relation between the pilot lottery instruments and baseline scores, so this change in middle school math estimates cannot be attributed to omitted variables bias. Rather, it stems from the loss of K-8 pilot schools in the lagged-score sample. We confirmed this by estimating middle school pilot effects with demographic controls in a sample that includes grade

\footnotetext{
${ }^{17}$ The sample analog of equation (4) can be thought of as a strategy that combines Wald estimates based on $Z_{i}$ across risk sets. Generalized Least Squares (GLS) estimation of the sample analog of equation (3) can be show to be the same as 2SLS using a full set of offer $\times$ risk set dummies as instruments (Angrist, 1991). Size-weighted least squares estimation of (4) is not algebraically the same as this 2SLS estimator, but should be close (and is indistinguishable from 2SLS in Panel A of the figure).
} 
6-to- 8 middle schools only. These results, reported in column 7 of Table 5 , show estimates similar to those with lagged score controls. The complementary sample that includes only K-8 schools generates small positive effects (not reported in the table. Thus, there is considerable heterogeneity in the pilot middle school math effects: grade 6-to-8 schools appear to be weaker than K-8 schools, at least as measured by their impact on MCAS math scores. It should also be noted, however, that the omission of $\mathrm{K} 2$ applicants to K-8 schools leads to a large drop in precision.

The results of adding an additional instrument to the charter lottery analysis are reported in column 3. The maintained instrument is a dummy for having been offered a charter seat any time after the relevant lottery, including off the waiting list ("eventual offer"), while the additional instrument is a dummy for having received an "initial offer" - that is, an offer of a seat in a charter school made immediately after the lottery was held. ${ }^{18}$ The multi-instrument models are over-identified so we can expect the resulting IV estimates to be more precise. In addition, the comparison of one- and twoinstrument estimates provides an over-identification test for the underlying exclusion restrictions. In practice, the two-instrument results are close to those using a single instrument, while precision gains are modest at best.

The final alternative specification reported in Table 5 is motivated by the unusual history of Health Careers Academy (HCA), a Horace Mann charter high school. As noted in the background section, HCA was born as a pilot school in 1995 but converted to a Horace Mann charter school in 1997. Horace Mann charter schools are like other charter schools in most respects, but their employees remain part of the BTU bargaining unit. For the reasons detailed in our earlier discussion, we believe HCA should be a seen as a charter school, albeit with union staff. Nevertheless, as a robustness check, we explored the implications of moving HCA from the charter to the pilot ledger. ${ }^{19}$

Reclassification of HCA as a pilot school has a modest effect on the charter lottery estimates: The estimated impact on high school math increases from $0.23 \sigma$ to $0.3 \sigma$ while the ELA effect falls from $0.19 \sigma$ to $0.11 \sigma$, as shown in column 4 of Table 5 . The latter estimate is no longer significantly different from zero, but this is due more to a drop in precision than to the changed estimate (reclassification of HCA shifts 300 observations). The charter writing impacts also change little. Addition of HCA to the sample of pilot high schools produces a marginally significant ELA effect of about $0.11 \sigma$ and an insignificant math effect of $0.09 \sigma$ (HCA becomes the third pilot high school in this case). The effects of pilot high school attendance on writing increase and are more precisely estimated with HCA included. The increase in ELA and math estimates when HCA is treated as a pilot school suggests

\footnotetext{
${ }^{18}$ The initial offer instrument can be constructed only for some schools; see appendix Table A1 for details.

${ }^{19}$ Like other charter schools, HCA uses a stand-alone lottery while pilot schools are part of the Boston assignment mechanism. When HCA is introduced into the sample of pilot high schools, we define risk sets according to whether applicants picked one of the other two pilot high schools as a first choice, picked HCA as a first choice, or applied to HCA with one or the other of the other two schools as a first choice in the BPS mechanism.
} 
that HCA may be stronger than the two pilot high schools that are otherwise in our lottery sample. On the other hand, the changes observed in this context are modest enough to be chance fluctuations.

A natural benchmark for the size of estimates reported here is the black-white test score gap. Among students attending regular BPS middle schools, blacks score about $0.7 \sigma$ below whites on ELA and $0.8 \sigma$ below whites in math. The charter middle school effects of $0.15 \sigma$ on middle school ELA scores is therefore enough to essentially close two-thirds of the black-white reading gap for students who remain enrolled in a charter middle school in grades 6-8. The even larger math gains of about $0.4 \sigma$ are more than enough to eliminate the racial gap in mathematics achievement while students are in middle school. The effects of roughly $0.2 \sigma$ estimated for high school ELA and math are also large enough to close the black-white high school gap of about $0.8 \sigma$ in both subjects (assuming four years of charter high school enrollment). Of course, these are extrapolations based on our per-year average effects and not direct estimates. In practice, we should expect some reduction in the returns to charter attendance over a long enough period. Moreover, these calculations assume that the effects reported in Table 4 apply equally to blacks and whites. On the other hand, separate estimation by race (not reported here in detail) suggests that this is indeed the case.

\section{Selective Attrition}

Tables 4 and 5 were constructed from samples of students who participate in charter school and pilot school lotteries and for whom we have post-lottery test scores. Lottery winners and losers should be similar at the time the lotteries are held, since a coin flip is all that distinguishes them. Subsequent attrition may lead to differences in the follow-up sample, however, unless the attrition process itself is also random. In other words, we worry about differential and selective attrition by win/loss status. For example, losers may be less likely to be found than winners, since students who lose the opportunity to attend a charter or pilot school may be more likely to leave the public schools altogether. Differential attrition generates selection bias (although those who leave Boston for another Massachusetts public school district should turn up in our sample). A simple test for selection bias looks at the impact of lottery offers on the probability lottery participants contribute MCAS scores to our analysis sample. If differences in follow-up rates are small, selection bias from differential attrition is also likely to be modest. ${ }^{20}$

Table 6 reports the mean follow-up rate for lottery participants in columns 1 and 4, and win-loss differentials in columns 2-3 and 5-6. Roughly 80 percent of charter lottery losers and about 70 percent of pilot lottery losers contribute a post-randomization test score. These high follow-up rates are due to

\footnotetext{
${ }^{20}$ More formally, if attrition can be described by a latent-index model of the sort commonly used to model discrete choice in econometrics, then selection bias in lottery comparisons arises only if winning the lottery affects the probability of MCAS participation. See, e.g., Angrist (1997).
} 
the fact that our extract is limited to those enrolled in BPS at baseline and to our use of a statewide MCAS data set. Follow-up differentials by win/loss status were estimated using regression models that parallel the reduced forms reported in Table 4. Positive coefficients indicate that lottery winners are more likely to contribute an MCAS score.

The estimated follow-up differentials for charter high school applicants are small and not significantly different from zero. For example, high school charter lottery winners are about 3 percentage points more likely to contribute an ELA score than losers (when the differential is estimated with demographic controls; see column 2). The follow-up differentials for charter middle school outcomes are a little larger, on the order of 4-5 percentage points. Although these small differences are marginally significant, they seem unlikely to impart substantial selection bias.

There are virtually no attrition differentials for pilot middle schools. The largest differentials turn up for participants in pilot high school lotteries, as can be seen in columns 5 and 6 of Table 6 . For example, controlling for demographic characteristics, high school winners are roughly 5 percentage points more likely to have taken the ELA test than losers, a significant effect with an estimated standard error of 2.6. But this too seems unlikely to explain our results, which show no effect on pilot lottery winners in high school. First, the most likely scenario for selective attrition has relatively high achieving losers dropping out. Second, the attrition differentials in this case are still fairly small. Nevertheless, as a check on the main findings, we discarded a few of the most imbalanced cohorts to construct a sample of charter middle school and pilot high school applicants with close-to-balanced attrition. We then re-estimated treatment effects using this balanced sample. Attrition differentials for balanced cohorts are reported in Appendix Table A3, while the corresponding lottery-based estimates of treatment effects are reported in A4. These results are similar to those reported in Table 4.

\section{The Anatomy of Charter and Pilot Treatment Effects}

\section{Charter and Pilot Compliers}

Our lottery-based research design uses random assignment to construct causal effects for the subpopulation that spends time in a charter or pilot school as a consequence of winning a lottery. What sort of schools do these students go to? Do the losers in this group remain in schools that look like the BPS average? Or, are the schools they come from unusual in some way? We're also interested in whether winning lottery participants end up in schools with a different socioeconomic and ability mix or go to schools with smaller classes. We address this set of questions using a causal IV framework to describe the school characteristics experienced by lottery applicants in alternative states of the world.

We begin by defining the causal relationship of interest to be the link between characteristics of 
schools and classmates and charter or pilot attendance. Let the attendance variable be $D_{i}$ for applicant $\mathrm{i}$, where this is recorded in the year immediately after application to schools in the relevant risk set. Let $X_{i}$ be a characteristic of these schools, such as the fraction nonwhite or class size. To capture the fact that $D_{i}$ affects school choice and therefore changes the characteristics of the school that applicant $i$ attends, we write

$$
X_{i}=X_{0 i}\left(1-D_{i}\right)+X_{1 i} D_{i}
$$

where $X_{0 i}$ and $X_{1 i}$ are the potential school characteristics that applicant $i$ would be exposed to if he or she attends a regular school or a charter or pilot school. The causal effect of charter or pilot attendance on $i$ is the difference in potential characteristics by school type, $X_{1 i}-X_{0 i}$.

Charter and pilot lottery compliers are applicants who would attend a charter or pilot school in the year after application if they win the lottery, but not otherwise. To describe this group formally, we write

$$
D_{i}=D_{0 i}\left(1-Z_{i}\right)+D_{1 i} Z_{i}
$$

where $D_{0 i}$ and $D_{1 i}$ are potential assignments that tell us the type of school applicant $i$ would attend if he or she wins or loses (as before, the instrument is $Z_{i}$, a dummy indicating lottery winners). Following Imbens and Angrist (1994), we impose monotonicity:

$$
D_{1 i} \geq D_{0 i}
$$

In other words, winning the lottery can only make charter or pilot attendance more likely. Given this restriction, $D_{1 i}-D_{0 i}$ is equal to zero or one.

In the causal IV framework developed by Angrist, Imbens, and Rubin (1996), the set of charter or lottery compliers consists of applicants with $D_{1 i}-D_{0 i}=1$. This happens when $D_{0 i}=0$ and $D_{1 i}=1$. Compliers are those who do not attend a charter or pilot school if they lose the lottery but do attend if they win. The rest of the population has $D_{1 i}-D_{0 i}=0$, because either $D_{1 i}=D_{0 i}=1$ (indicating applicants who attend whether they win or not, the always-takers) or $D_{1 i}=D_{0 i}=0$ (indicating applicants who do not attend whether they win or not, the never-takers). Always-takers' and never-takers' are unaffected by the lottery, so IV estimates using lottery instruments do not reflect the impact of charter or pilot attendance on these two groups. Replacing years-in-charter or pilot with a dummy for charter or pilot attendance, and using $Y_{1 i}$ and $Y_{0 i}$ to denote potential test score outcomes, IV identifies the average causal effect on compliers,

$$
E\left[Y_{1 i}-Y_{0 i} \mid D_{1 i} \geq D_{0 i}\right]
$$


This is the local average treatment effect (LATE) captured by lottery instruments. ${ }^{21}$

Here we are interested in the school environment or school characteristics rather than test scores. Moreover, we focus on the average type of schools attended by compliers in alternative states if the world rather than the treatment effect on school type. In other words, the parameters of interest are

$$
\begin{aligned}
& \alpha_{1 c} \equiv E\left[X_{1 i} \mid D_{1 i} \geq D_{0 i}\right] \\
& \alpha_{0 c} \equiv E\left[X_{0 i} \mid D_{1 i} \geq D_{0 i}\right]
\end{aligned}
$$

We think of $\alpha_{0 c}$ as the fallback position for compliers unable to attend the type of school to which they applied (because they lost the lottery); $\alpha_{1 c}$ describes the schools attended by compliers whose lottery applications were successful. Abadie (2002) shows that these marginal means can be estimated by using $Z_{i}$ as instrument for the following second-stage equations (ignoring covariates):

$$
\begin{aligned}
D_{i} X_{i} & =\lambda_{1 c}+\alpha_{1 c} D_{i}+\xi_{1 i} \\
\left(1-D_{i}\right) X_{i} & =\lambda_{0 c}+\alpha_{0 c}\left(1-D_{i}\right)+\xi_{0 i},
\end{aligned}
$$

where $\lambda_{1 c}$ and $\lambda_{0 c}$ are terms that incorporate controls - in this case dummies for risk sets. ${ }^{22}$

Compliers who lose the lottery end up in schools with a demographic mix similar to the systemwide BPS average. This can be seen in columns 1 and 5 of Table 7 for charter applicants and columns 3 and 7 for pilot applicants. For example, the average proportion black in BPS middle schools is 47 percent (a statistic from Table 2). Non-treated charter compliers attend middle schools that are also 47 percent Black while non-treated pilot compliers attend middle schools that are 46 percent Black. Likewise, the average proportion Black in BPS high schools is 0.51, while non-treated compliers attend high schools that are 55 percent Black.

In some respects, the complier fallback position is somewhat better than the BPS average. This suggests that charter treatment effects cannot be explained by arguing that the regular BPS schools they would otherwise attend have unusually low-achieving peers. At losers' middle schools, for example, the mean baseline scores of peers are positive while the overall BPS average is negative. In high school, peer means for losers are higher than the BPS average for math though about the same for ELA scores. Socioeconomic status as measured by the proportion getting a free or reduced price

\footnotetext{
${ }^{21}$ LATE can be generalized to covered ordered treatments such as years in charter or pilot, and models with covariates; see Angrist and Pischke (2009) for details.

${ }^{22}$ Abadie (2002) uses equations like (5) and (6) to estimate the marginal distribution of potential outcomes for compliers, but his approach works for characteristics as well. Because we use a saturated model for controls (risk sets), 2SLS estimates of $\alpha_{1 c}$ and $\alpha_{0 c}$ are the same as those that would be generated using Abadie's (2003) kappa-weighting scheme to estimate compliers' marginal means.
} 
lunch is also higher at the fallback schools than in traditional BPS schools (e.g., compare 0.77 and 0.67 in columns 1 and 5 of Table 7 with BPS means of 0.89 and 0.85 ). Class sizes at these schools are smaller than the traditional BPS average. Also noteworthy is the fact that the characteristics of fallback schools are similar for pilot and charter lottery applicants.

Successful charter and pilot compliers attend middle schools that have fewer minorities than the schools attended by losers. In high school, however, wining compliers have more Black and female classmates (though fewer Hispanic classmates) than losers. Other differences in school environment include fewer SPED and LEP students and higher baseline scores at the charter middle schools attended by winners. For example, the peer mean middle school ELA score for winners is 0.35 versus 0.11 for losers. For high school compliers, the peer mean math score is 0.05 versus -0.385 for losers. On the other hand, pilot compliers experience similar differentials: among both middle and high school compliers, peer mean baseline scores are higher, there are fewer LEP and SPED students, and the average proportion receiving a free or reduced price lunch is lower for winners than for losers. This weighs against a pure peer effect interpretation of charter students gains, since a similar peer differential does not produce gains for pilot compliers. Its worth noting, however, that charter middle school compliers end up in smaller classes if they win the lottery. Pilot compliers, by contrast, attend schools with larger classes.

\section{Ability Interactions and Peer Effects}

The distribution of school characteristics described in Table 7, as well as the fact that charter applicants are positively selected, motivates our analysis of treatment effect heterogeneity. Specifically, we explore treatment effect interactions with an applicants' own ability and interactions with the ability of peers. The interaction with own ability addresses the question of whether charter and pilot schools cater to a relatively high-ability group since charter applicants (and pilot high school applicants) have higher baseline scores. The interaction with peer ability provides some evidence on the extent to which peer effects might explain our findings.

The equation used to estimate models with interaction terms looks like this:

$$
y_{i g t}=\alpha_{t}+\beta_{g}+\sum_{j} \delta_{j} d_{i j}+\gamma^{\prime} X_{i}+\rho_{0} S_{i g t}+\rho_{1} A_{i}\left(S_{i g t}-s_{g}\right)+\epsilon_{i g t}
$$

where $A_{i}$ is student $i$ 's baseline score and $s_{g}$ is the average score in the sample, so that the main effect, $\rho_{0}$, is evaluated at the mean. ${ }^{23}$ The set of covariates, $X_{i}$, includes baseline scores. The interaction

\footnotetext{
${ }^{23}$ The variables $A_{i}$ and $s_{g}$ are fixed in any given sample, including those that pool grades, but vary for a given applicant from middle to high school.
} 
term of interest is $\rho_{1}$. The corresponding first stage equations are

$$
\begin{aligned}
S_{i g t} & =\lambda_{1 t}+\kappa_{1 g}+\sum_{j} \mu_{1 j} d_{i j}+\Gamma_{1}^{\prime} X_{i}+\pi_{10} Z_{i}+\pi_{11} A_{i} Z_{i}+\eta_{1 i g t} \\
A_{i}\left(S_{i g t}-s_{g}\right) & =\lambda_{2 t}+\kappa_{2 g}+\sum_{j} \mu_{2 j} d_{i j}+\Gamma_{2}^{\prime} X_{i}+\pi_{20} Z_{i}+\pi_{21} A_{i} Z_{i}+\eta_{2 i g t},
\end{aligned}
$$

so that equation (7) is identified by adding an interaction between $A_{i}$ and $Z_{i}$ to the instrument list.

The effects of charter middle school attendance are larger for students with lower baseline scores, though the estimated interaction terms are small. This can be seen in the second column of Table 8, which reports 2 SLS estimate of $\rho_{1}$ in equation (7). For example, a lottery applicant with a baseline score $0.2 \sigma$ below the mean is estimated to have an ELA score gain that is $0.02 \sigma$ higher $(0.094 * 0.2=$ $0.019)$ and a math score gain that is $0.027 \sigma$ higher $(0.137 * 0.2)$ than an applicant with a baseline score at the mean. None of the estimated own-ability interaction terms for applicants to charter high school are significantly different from zero. These results weigh against the view that charter schools focus on high achieving applicants.

The one (marginally) significant own-ability interaction for pilot schools is that for high school math scores. This interaction term is of the same order of magnitude as the charter interaction terms for middle school. On the other hand, no significant own-ability interactions emerge from the analysis of treatment effects in pilot middle schools. Thus, the evidence in column 4 suggests that to the extent that effects in either charter or pilot schools vary with students' baseline scores, those with lower scores benefit more, especially in the charter case. Overall, however, the variation in treatment effects with pre-treatment scores is modest.

Table 8 also shows little evidence of peer effects of the usual sort. In particular, columns (6) and (8) report 2 SLS estimates of $\rho_{1}$ in equation (7) when $A_{i}$ is mean baseline score in the risk set. We might think, for example, that one of the benefits of charter attendance is the opportunity to attend schools with higher-achieving peers. In practice, however, the score gain from charter middle school attendance varies inversely with peer achievement. For example students, who apply to schools in a risk set with peer means $0.1 \sigma$ above the sample mean are estimated to have an ELA gain that is reduced by $0.07 \sigma$ and a math gain that is reduced by $0.1 \sigma$ for each year in charter. These negative interactions are noteworthy since the charter effect on middle school math scores is the most dramatic result reported here. A marginally significant positive peer interaction appears for charter effects on high school math scores, but this is the only evidence we have for interactions with peer means in charter high schools. The corresponding interaction term for ELA, for example, is only $0.05 \sigma$ with a much larger standard error. There is one significant peer interaction for pilot applicants in the effect of 
middle school on math scores. It should be noted, however, that many of the peer-mean interactions are imprecisely estimated, especially for pilot high schools.

\section{Observational Estimates}

Our lottery analysis use a sample of applicants and schools for which lotteries are both relevant and documented. To gauge the generality of the lottery findings, we also estimated the effects of charter and pilot school attendance in a larger sample that includes all Boston schools. In this case, identification of causal effects is based on statistical controls for family background and earlier achievement. We refer to this analysis as an "observational study", to distinguish it from the quasi-experimental lotterybased identification strategy. The observational results consist of OLS estimates of equations like (1), controlling for student demographics and baseline scores.

The data structure for the observational analysis is similar to that used for the quasi-experimental study. Baseline scores and demographics for middle school come from 4th grade data, while baseline scores and demographics for high school come from 8th grade data. The regressors of interest count years spent attending a charter or pilot school at the relevant level (e.g., years in a charter middle school, in grades 6-8), as well as time spent in an exam or alternative school. Specifically, the observational estimates were constructed by fitting

$$
y_{i g t}=\alpha_{t}+\beta_{g}+\gamma^{\prime} X_{i}+\rho_{c} C_{i g t}+\rho_{p} P_{i g t}+\rho_{e} E_{i g t}+\rho_{\mathrm{alt}} \mathrm{ALT}_{i g t}+\epsilon_{i g t}
$$

where $C_{i g t}, P_{i g t}, E_{i g t}$, and $\mathrm{ALT}_{i g t}$ denote years in a charter, pilot, exam, or alternative school, with corresponding effects, $\rho_{c}, \rho_{p}, \rho_{e}$, and $\rho_{\text {alt }}$. To parallel the exclusion of K-8 pilot school applicants in the lottery analysis with baseline scores, the observational analysis that controls for baseline scores is estimated on samples that omit students who attended elementary grades in a K-8 pilot.

The observational charter results, reported in Table 9, are positive and significantly different from zero for every score outcome except elementary school math. Moreover, at every grade level and for every test, the charter estimates are more positive than the pilot estimates. Control for baseline scores has surprisingly little effect on the charter estimates. In models with baseline score controls, each year spent at a charter middle school is estimated to increase ELA scores by about $0.1 \sigma$ and to increase math scores by about $0.18 \sigma$. In contrast, the corresponding estimates for pilot middle schools are significant and negative, on the order of $-0.08 \sigma$ for ELA and $-0.1 \sigma$ for math. For both pilot schools and charter schools, the high school effects in Table 9 are positive and significant for all score outcomes, though the estimated charter effects are consistently larger than the parallel estimates for pilots. The charter effects in elementary school are also larger than those for elementary school pilots; 
neither of the pilot estimates in this case is significant.

The observational results in Table 9 are broadly consistent with the lottery results, but the magnitudes differ. For example, the charter middle school effects in Table 9, while still positive and economically and statistically significant, are smaller than those reported in Table 4. Is this difference due to selection bias or to the broader coverage of the observational sample? Table 10 addresses this question by showing observational results in and out of the lottery sample, alongside the corresponding lottery estimates. These estimates were constructed by replacing the terms $\rho_{c} C_{i g t}$ and $\rho_{p} P_{i g t}$ in equation (10) with terms that allow for separate effects for time spent in schools in and out of the set of schools in the lottery sample. For example, we replace $\rho_{c} C_{i g t}$ with $\rho_{l c} C_{\text {ligt }}+\rho_{n c} C_{n i g t}$ where $C_{\text {ligt }}$ counts years spent in a charter school that is included in the lottery sample and $C_{\text {nigt }}$ counts non-lottery charter years (note that $C_{i g t}=C_{\text {ligt }}+C_{\text {nigt }}$ ). The observational estimates reported in Table 10 control for baseline scores.

Allowing the effects of time spent in schools in an out of the lottery sample to differ goes a long way towards reconciling the observational and lottery estimates, especially for charter schools. For example, the observational estimates of the effects of time attending a charter middle school in the lottery sample are $0.16 \sigma$ for ELA and $0.31 \sigma$ for math. These estimates are not too far from the corresponding lottery estimates with baseline scores $(0.14 \sigma$ for ELA and $0.39 \sigma$ for math). The high school estimates are also a good match: compare, for example, observational estimates of ELA effects of about $0.19 \sigma$ using both designs.

Because the lottery and observational estimates of charter effects line up reasonably well when estimated for schools in the same sample, the results in Table 10 support the notion that the observational study design does a good job of controlling for selection bias in this case. On the other hand, the table also suggests that the charter schools in our lottery sample are among the best in the city. Observational estimates of the effects of time spent in the charter schools not included in our lottery sample, while still economically and statistically significant for every outcome, are uniformly smaller than the corresponding estimates for the effects of time spent in lottery-sample schools.

The observational and lottery-based analyses of pilot middle schools are also broadly consistent in that both produce negative effects in the sample that includes lagged scores. The observational results for ELA are more negative than the corresponding lottery estimates, while the opposite is true for math. The match across designs is not as good for the high school results, where the observational analysis using the lottery sample produces substantial and significant positive effects for all outcomes. In contrast, the lottery results for high school ELA and math are small and not significantly different from zero (though the match for writing is good). The variance across designs may be due to the fact that the lottery estimates for pilot high schools are not very precise. Also noteworthy is the fact that 
small positive effects of pilot attendance on elementary school achievement turn up using both the observational and lottery designs.

On balance, as with the charter results, Table 10 mostly reinforces the lottery findings for pilots. Moreover, with the exception of middle schools, the observational estimates of pilot-school treatment effects are also larger for schools used in the lottery sample than for other pilot schools. Like the middle school effects, the estimated impacts of time spent at a non-lottery elementary school pilot are negative.

\section{Summary and Conclusions}

Lottery-based estimates of the impact of charter attendance on student achievement in Boston show impressive score gains in middle and high school. We also evaluate an alternative to the charter model, Boston's pilot schools. Lottery-based estimates for pilot schools are small and mostly insignificant. In an effort to gauge the generality of our lottery-based findings, we complement the quasi-experimental lottery analysis with an observational study of the full set of charter and pilot schools. This approach produces estimates similar to the lottery-based estimates for the sample of charter schools that have lotteries, lending credence to the observational analysis.

Across study designs and samples, the estimate effects of attending a pilot school are smaller than the corresponding charter estimates. Although we cannot say pinpoint the source of differential impacts, a number of factors seem likely to be important. The student-teacher ratio is much smaller in the charter schools, and the school day and school year are considerably longer. On both of these dimensions, pilot schools are closer to traditional Boston public schools than they are to charter schools. These differences may originate in collective bargaining constraints that make it more expensive for pilot schools to expand instructional hours and staff their schools with more teachers per student. In addition, many of the charter schools in our sample use elements of the No Excuses model, an instructional paradigm that is not common in public schools, pilot or otherwise.

A natural benchmark for our estimates is the black-white test score gap. Among students attending regular BPS middle schools, blacks score about 0.7 standard deviations below whites in language arts and 0.8 standard deviations below whites in math. Our estimated charter school effects are large enough to reduce the black-white reading gap in middle school by two-thirds. The even larger math gains (about 0.4 standard deviations) are more than enough to eliminate the racial gap in math while students are in middle school. The effects of roughly 0.2 standard deviations estimated for high school ELA and math are also large enough to close the black-white high school gap of about 0.8 standard deviations in both subjects (assuming four years of charter high school enrollment). 
It bears repeating that the lottery results reported here do not estimate overall charter and pilot school effects, even for Boston. Rather, the lottery results are generated by schools that parents find most appealing and, in the case of charter schools, those that have well-documented lotteries and that continue to operate. Perhaps not surprisingly, our observational analysis suggests that the schools in our charter lottery sample are among the most effective charter schools. On the other hand, results for this relatively effective set of schools seem likely to be of considerable policy interest. Massachusetts, along with a number of other states, caps the number of charter schools, while the U.S. Department of Education is pressing states to lift these caps. It seems likely that over-subscribed and well-run schools will be the first to expand if caps are lifted. State regulators might also reasonably choose to encourage replication of schools that have documented effectiveness and high demand. 
Table 1: Teacher Characteristics by School Type

\begin{tabular}{|c|c|c|c|c|c|c|c|}
\hline & \multirow{2}{*}{$\begin{array}{c}\text { Traditional } \\
\text { BPS Schools } \\
\text { (1) }\end{array}$} & \multicolumn{4}{|c|}{ Pilot, Charter, Exam or Alternative School } & \multicolumn{2}{|c|}{ Lottery Sample } \\
\hline & & $\begin{array}{c}\text { Charter } \\
(2)\end{array}$ & $\begin{array}{l}\text { Pilot } \\
(3)\end{array}$ & $\begin{array}{c}\text { Exam } \\
(4)\end{array}$ & $\begin{array}{c}\text { Alternative } \\
\text { (5) }\end{array}$ & $\begin{array}{c}\text { Charter } \\
(7)\end{array}$ & $\begin{array}{l}\text { Pilot } \\
(8)\end{array}$ \\
\hline \multicolumn{8}{|c|}{ I. Elementary School (3rd and 4th grades) } \\
\hline Teachers licensed to teach assignment & $86.0 \%$ & $60.0 \%$ & $73.2 \%$ & - & $70.6 \%$ & - & $71.9 \%$ \\
\hline Core classes taught by highly qualified teachers & $90.6 \%$ & $61.3 \%$ & $78.2 \%$ & - & $56.6 \%$ & - & $77.8 \%$ \\
\hline Student/Teacher ratio & 15.7 & 11.4 & 15.9 & - & 6.9 & - & 15.8 \\
\hline Proportion of teachers 32 and younger & $26.6 \%$ & $64.5 \%$ & $51.8 \%$ & - & $27.3 \%$ & - & $50.4 \%$ \\
\hline Proportion of teachers 49 and older & $39.9 \%$ & $8.0 \%$ & $11.9 \%$ & - & $31.6 \%$ & - & $11.1 \%$ \\
\hline Number of schools & 72 & 3 & 7 & - & 2 & - & 5 \\
\hline \multicolumn{8}{|c|}{ II. Middle School (6th, 7th, and 8th grades) } \\
\hline Teachers licensed to teach assignment & $77.8 \%$ & $53.9 \%$ & $65.8 \%$ & $90.8 \%$ & $48.6 \%$ & $54.4 \%$ & $65.5 \%$ \\
\hline Core classes taught by highly qualified teachers & $84.8 \%$ & $70.4 \%$ & $70.2 \%$ & $94.5 \%$ & $45.4 \%$ & $73.1 \%$ & $69.8 \%$ \\
\hline Student/Teacher ratio & 16.1 & 11.9 & 19.5 & 21.1 & 5.2 & 11.9 & 19.6 \\
\hline Proportion of teachers 32 and younger & $27.1 \%$ & $74.5 \%$ & $55.0 \%$ & $30.0 \%$ & $28.6 \%$ & $81.1 \%$ & $54.4 \%$ \\
\hline Proportion of teachers 49 and older & $36.0 \%$ & $4.8 \%$ & $13.6 \%$ & $43.3 \%$ & $27.8 \%$ & $1.3 \%$ & $13.9 \%$ \\
\hline Number of schools & 28 & 11 & 7 & 3 & 4 & 5 & 6 \\
\hline \multicolumn{8}{|c|}{ III. High School (10th grade) } \\
\hline Teachers licensed to teach assignment & $80.9 \%$ & $57.6 \%$ & $64.1 \%$ & $90.7 \%$ & $75.8 \%$ & $57.7 \%$ & $73.5 \%$ \\
\hline Core academic teachers identified as highly qualified & $85.7 \%$ & $78.6 \%$ & $72.7 \%$ & $94.3 \%$ & $80.6 \%$ & $82.1 \%$ & $83.6 \%$ \\
\hline Student/Teacher ratio & 17.6 & 10.9 & 16.0 & 21.1 & 8.9 & 10.6 & 17.5 \\
\hline Proportion of teachers 32 and younger & $31.9 \%$ & $66.9 \%$ & $44.7 \%$ & $30.0 \%$ & $29.7 \%$ & $64.3 \%$ & $41.3 \%$ \\
\hline Proportion of teachers 49 and older & $40.3 \%$ & $6.9 \%$ & $15.0 \%$ & $43.9 \%$ & $25.3 \%$ & $8.2 \%$ & $7.7 \%$ \\
\hline Number of schools & 22 & 8 & 7 & 3 & 4 & 4 & 2 \\
\hline
\end{tabular}

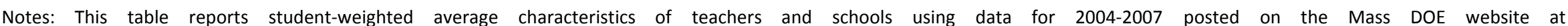

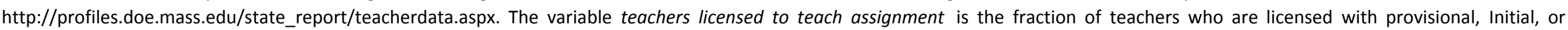

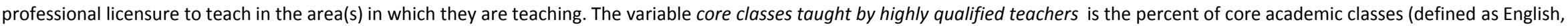

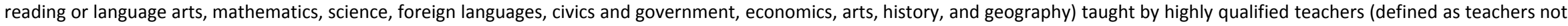

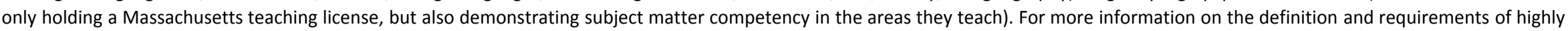
qualified teachers, see http://www.doe.mass.edu/nclb/hq/hq_memo.html. 
Table 2: Descriptive Statistics

\begin{tabular}{|c|c|c|c|c|c|c|c|}
\hline & \multirow{2}{*}{$\begin{array}{c}\text { Traditional BPS } \\
\text { Schools } \\
(1)\end{array}$} & \multicolumn{2}{|c|}{ Enrolled in Pilot or Charter } & \multicolumn{2}{|c|}{ Applicants in Lottery Sample } & \multicolumn{2}{|c|}{$\begin{array}{c}\text { Applicants in Lottery Sample } \\
\text { with Baseline Scores }\end{array}$} \\
\hline & & $\begin{array}{c}\text { Charter } \\
(2)\end{array}$ & $\begin{array}{l}\text { Pilot } \\
(3)\end{array}$ & $\begin{array}{c}\text { Charter } \\
(4)\end{array}$ & $\begin{array}{l}\text { Pilot } \\
(5)\end{array}$ & $\begin{array}{c}\text { Charter } \\
(6)\end{array}$ & $\begin{array}{l}\text { Pilot } \\
(7)\end{array}$ \\
\hline \multicolumn{8}{|c|}{ I. Elementary School (3rd and 4th grades) } \\
\hline Female & $48.3 \%$ & $52.4 \%$ & $48.4 \%$ & - & $50.6 \%$ & - & - \\
\hline Black & $43.4 \%$ & $72.0 \%$ & $43.3 \%$ & - & $54.3 \%$ & - & - \\
\hline Hispanic & $34.5 \%$ & $15.9 \%$ & $32.0 \%$ & - & $22.0 \%$ & - & - \\
\hline Special education & $10.4 \%$ & $6.3 \%$ & $10.7 \%$ & - & $9.9 \%$ & - & - \\
\hline Free or reduced price lunch & $83.2 \%$ & $67.8 \%$ & $69.1 \%$ & - & $66.5 \%$ & - & - \\
\hline Limited English proficiency & $28.8 \%$ & $3.8 \%$ & $19.3 \%$ & - & $7.0 \%$ & - & - \\
\hline Years in charter & 0.016 & 4.558 & 0.009 & - & 0.222 & - & - \\
\hline Years in pilot & 0.031 & 0.023 & 3.801 & - & 1.803 & - & - \\
\hline Number of students & 10,443 & 656 & 823 & - & 573 & - & - \\
\hline \multicolumn{8}{|c|}{ II. Middle School (6th, 7th, and 8th grades) } \\
\hline Female & $47.0 \%$ & $48.9 \%$ & $49.9 \%$ & $48.3 \%$ & $52.6 \%$ & $48.2 \%$ & $54.9 \%$ \\
\hline Black & $46.9 \%$ & $69.4 \%$ & $50.5 \%$ & $59.2 \%$ & $49.8 \%$ & $59.1 \%$ & $50.6 \%$ \\
\hline Hispanic & $37.3 \%$ & $19.0 \%$ & $28.3 \%$ & $19.4 \%$ & $31.2 \%$ & $19.6 \%$ & $35.0 \%$ \\
\hline Special education & $24.5 \%$ & $18.5 \%$ & $21.4 \%$ & $19.3 \%$ & $17.5 \%$ & $19.1 \%$ & $18.2 \%$ \\
\hline Free or reduced price lunch & $89.3 \%$ & $73.1 \%$ & $85.6 \%$ & $69.1 \%$ & $79.3 \%$ & $69.1 \%$ & $87.8 \%$ \\
\hline Limited English proficiency & $21.8 \%$ & $7.1 \%$ & $21.0 \%$ & $7.7 \%$ & $15.0 \%$ & $7.8 \%$ & $18.0 \%$ \\
\hline 4th Grade Math Score & -0.119 & -0.069 & -0.196 & 0.167 & -0.077 & 0.167 & -0.077 \\
\hline 4th Grade ELA Score & -0.113 & 0.080 & -0.127 & 0.235 & -0.018 & 0.235 & -0.018 \\
\hline Years in charter & 0.018 & 2.458 & 0.012 & 1.480 & 0.220 & 1.469 & 0.221 \\
\hline Years in pilot & 0.023 & 0.033 & 2.149 & 0.120 & 0.954 & 0.119 & 1.054 \\
\hline Number of students & 12,257 & 2,382 & 2,696 & 1,355 & 1,917 & 1,331 & 1,298 \\
\hline \multicolumn{8}{|c|}{ III. High School (10th grade) } \\
\hline Female & $50.1 \%$ & $59.9 \%$ & $52.2 \%$ & $59.1 \%$ & $44.7 \%$ & $59.0 \%$ & $44.8 \%$ \\
\hline Black & $50.9 \%$ & $65.8 \%$ & $53.8 \%$ & $67.6 \%$ & $58.1 \%$ & $67.6 \%$ & $57.9 \%$ \\
\hline Hispanic & $36.1 \%$ & $15.6 \%$ & $26.7 \%$ & $23.0 \%$ & $24.9 \%$ & $22.9 \%$ & $25.0 \%$ \\
\hline Special education & $22.8 \%$ & $14.8 \%$ & $17.5 \%$ & $15.5 \%$ & $12.7 \%$ & $15.3 \%$ & $12.6 \%$ \\
\hline Free or reduced price lunch & $84.7 \%$ & $66.7 \%$ & $77.1 \%$ & $75.7 \%$ & $78.5 \%$ & $76.1 \%$ & $79.0 \%$ \\
\hline Limited English proficiency & $18.9 \%$ & $3.9 \%$ & $7.2 \%$ & $4.2 \%$ & $5.5 \%$ & $4.1 \%$ & $5.6 \%$ \\
\hline 8th Grade Math Score & -0.288 & 0.131 & 0.059 & 0.092 & 0.163 & 0.092 & 0.163 \\
\hline 8th Grade ELA Score & -0.187 & 0.231 & 0.148 & 0.193 & 0.209 & 0.193 & 0.209 \\
\hline Years in charter & 0.013 & 2.012 & 0.023 & 0.483 & 0.971 & 0.484 & 0.970 \\
\hline Years in pilot & 0.006 & 0.009 & 1.951 & 0.719 & 0.269 & 0.718 & 0.271 \\
\hline Number of students & 9,135 & 1,149 & 1,949 & 1,957 & 1,010 & 1,934 & 1,003 \\
\hline Number of schools & 23 & 8 & 7 & 4 & 2 & 4 & 2 \\
\hline \multicolumn{8}{|c|}{$\begin{array}{l}\text { Notes: The table reports sample means in baseline years by school type. The numbered notes below describe each sample. Demographic characteristics are taken from grade K2 for } \\
\text { elementary school students, grade } 4 \text { for middle school students, and grade } 8 \text { for high school students. All students in the sample reside in Boston and were enrolled in BPS or a charter } \\
\text { school in the baseline year. To be included, students must have at least one MCAS score among the following: ELA and Math for elementary and middle school students; ELA, Math, } \\
\text { Writing Topic, and Writing Composition for high school students. }\end{array}$} \\
\hline \multicolumn{8}{|c|}{ 1. BPS students excluding exam, alternative, charter and pilot students from 2004-2008. } \\
\hline \multicolumn{8}{|c|}{ 2. Students enrolled in charter schools from 2004-2008. } \\
\hline \multicolumn{8}{|c|}{ 3. Students enrolled in pilot schools from 2004-2008. } \\
\hline 4. Charter applicant cohorts in rand & mized lotteries: mid & ol stude & 07 , anc & ol studen & & & \\
\hline & & & & & & & \\
\hline
\end{tabular}


Table 3: Covariate Balance with Lottery Winners minus Lottery Losers at Charter and Pilot Schools

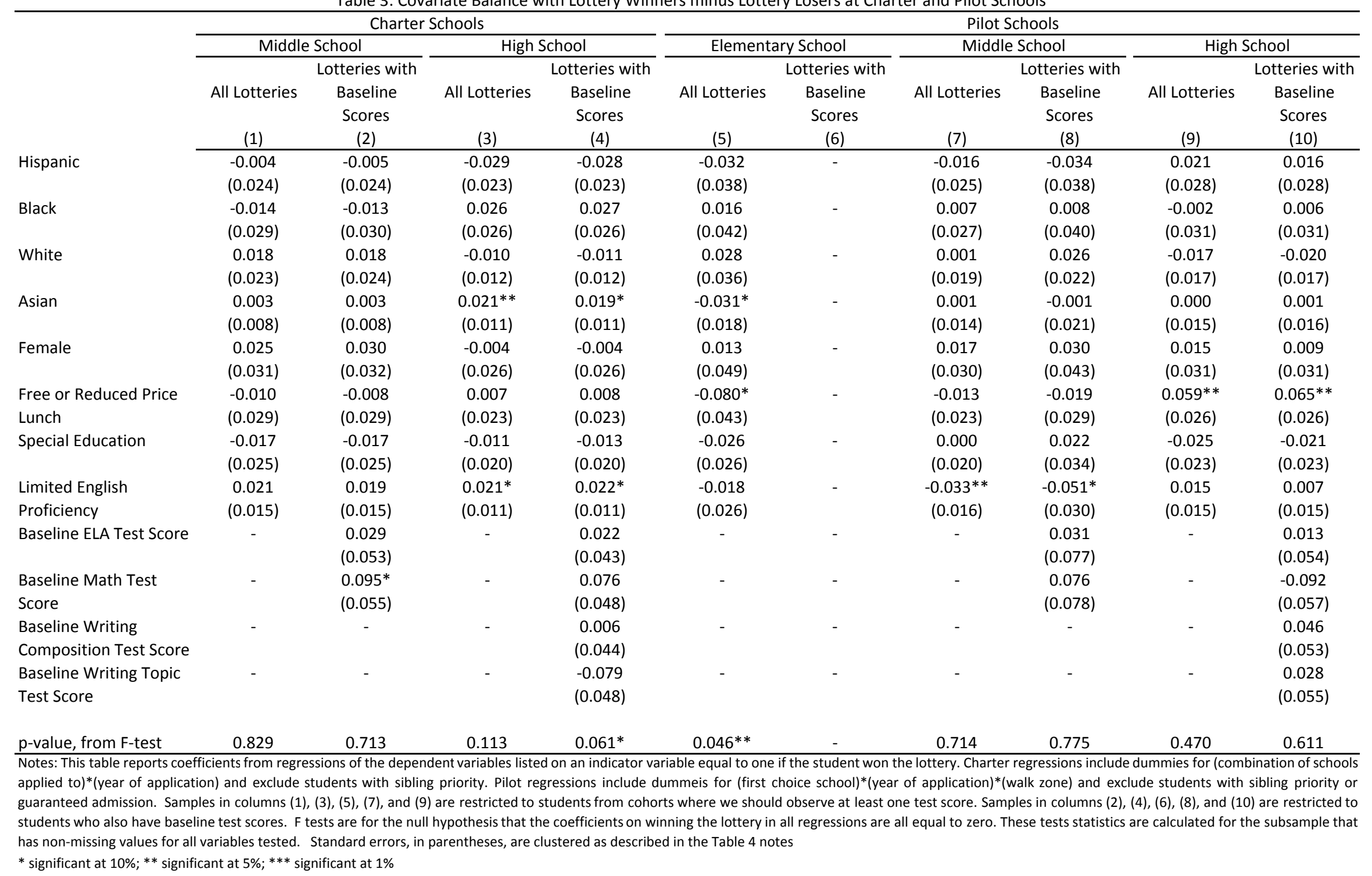


Table 4: Lottery Results

\begin{tabular}{|c|c|c|c|c|c|c|c|c|c|c|}
\hline \multirow[b]{2}{*}{ Level } & \multirow[b]{2}{*}{ Subject } & \multicolumn{5}{|c|}{ Charter } & \multicolumn{4}{|c|}{ Pilots } \\
\hline & & & $\begin{array}{c}\text { First Stage } \\
\text { (1) }\end{array}$ & $\begin{array}{l}\text { Reduced Form } \\
\text { (2) }\end{array}$ & $\begin{array}{c}2 S L S \\
(3)\end{array}$ & $\begin{array}{c}2 \text { 2SLS w/demos } \\
(4)\end{array}$ & $\begin{array}{c}\text { First Stage } \\
(5)\end{array}$ & $\begin{array}{c}\text { Reduced Form } \\
\text { (6) }\end{array}$ & $\begin{array}{c}2 S L S \\
(7)\end{array}$ & $\begin{array}{c}2 \text { SLS w/demos } \\
\text { (8) }\end{array}$ \\
\hline \multicolumn{11}{|c|}{ Elementary School } \\
\hline & \multirow[t]{2}{*}{ ELA } & & - & - & - & - & $\begin{array}{c}2.852^{* * *} \\
(0.193)\end{array}$ & $\begin{array}{c}0.196 * * \\
(0.078)\end{array}$ & $\begin{array}{c}0.069 * * \\
(0.027)\end{array}$ & $\begin{array}{c}0.064^{* * *} \\
(0.024)\end{array}$ \\
\hline & & $\mathrm{N}$ & & & & & & 876 & & 876 \\
\hline & \multirow[t]{2}{*}{ Math } & & - & - & - & - & $\begin{array}{c}2.858^{* * *} \\
(0.194)\end{array}$ & $\begin{array}{l}0.177^{* *} \\
(0.078)\end{array}$ & $\begin{array}{l}0.062^{* *} \\
(0.027)\end{array}$ & $\begin{array}{l}0.060^{* *} \\
(0.026)\end{array}$ \\
\hline & & $\mathrm{N}$ & & & & & & 874 & & 874 \\
\hline \multicolumn{11}{|c|}{ Middle School } \\
\hline & \multirow[t]{2}{*}{ ELA } & & $0.965^{* * *}$ & $0.181 * * *$ & $0.187^{* * *}$ & $0.149 * * *$ & $1.378^{* * *}$ & 0.021 & 0.016 & 0.006 \\
\hline & & $\mathrm{N}$ & $(0.114)$ & $\begin{array}{l}(0.061) \\
2,416\end{array}$ & $(0.062)$ & $\begin{array}{c}(0.052) \\
2,416\end{array}$ & $(0.189)$ & $\begin{array}{c}(0.065) \\
3,390\end{array}$ & $(0.047)$ & $\begin{array}{c}(0.043) \\
3,390\end{array}$ \\
\hline & \multirow[t]{2}{*}{ Math } & & $\begin{array}{c}0.918^{* * *} \\
(0.108)\end{array}$ & $\begin{array}{c}0.397 * * * \\
(0.067)\end{array}$ & $\begin{array}{c}0.432^{* * *} \\
(0.075)\end{array}$ & $\begin{array}{c}0.405 * * * \\
(0.066)\end{array}$ & $\begin{array}{c}1.291^{* * *} \\
(0.181)\end{array}$ & $\begin{array}{l}-0.078 \\
(0.069)\end{array}$ & $\begin{array}{l}-0.060 \\
(0.053)\end{array}$ & $\begin{array}{l}-0.059 \\
(0.048)\end{array}$ \\
\hline & & $\mathrm{N}$ & & 2,582 & & 2,582 & & 3,851 & & 3,851 \\
\hline \multicolumn{11}{|c|}{ High School } \\
\hline & \multirow[t]{2}{*}{ ELA } & & $\begin{array}{c}0.742^{* * *} \\
(0.139)\end{array}$ & $\begin{array}{c}0.147^{* * *} \\
(0.053)\end{array}$ & $\begin{array}{c}0.199 * * * \\
(0.062)\end{array}$ & $\begin{array}{c}0.187^{* * *} \\
(0.055)\end{array}$ & $\begin{array}{c}0.644^{* * *} \\
(0.108)\end{array}$ & $\begin{array}{c}0.013 \\
(0.049)\end{array}$ & $\begin{array}{c}0.020 \\
(0.075)\end{array}$ & $\begin{array}{c}0.007 \\
(0.073)\end{array}$ \\
\hline & & $N$ & & 1,947 & & 1,947 & & 1,007 & & 1,007 \\
\hline & \multirow[t]{2}{*}{ Math } & & $\begin{array}{c}0.738^{* * *} \\
(0.137)\end{array}$ & $\begin{array}{c}0.235^{* * *} \\
(0.059)\end{array}$ & $\begin{array}{c}0.318^{* * *} \\
(0.077)\end{array}$ & $\begin{array}{c}0.274^{* * *} \\
(0.071)\end{array}$ & $\begin{array}{c}0.632^{* * *} \\
(0.108)\end{array}$ & $\begin{array}{c}0.013 \\
(0.065)\end{array}$ & $\begin{array}{c}0.021 \\
(0.100)\end{array}$ & $\begin{array}{l}-0.011 \\
(0.101)\end{array}$ \\
\hline & & $N$ & & 1,929 & & 1,929 & & 996 & & 996 \\
\hline & \multirow[t]{2}{*}{ Writing Topic } & & $\begin{array}{c}0.741^{* * *} \\
(0.138)\end{array}$ & $\begin{array}{c}0.206 * * * \\
(0.069)\end{array}$ & $\begin{array}{c}0.278^{* * *} \\
(0.083)\end{array}$ & $\begin{array}{c}0.267 * * * \\
(0.078)\end{array}$ & $\begin{array}{c}0.636^{* * *} \\
(0.109)\end{array}$ & $\begin{array}{c}0.119 * * \\
(0.059)\end{array}$ & $\begin{array}{l}0.187^{* *} \\
(0.093)\end{array}$ & $\begin{array}{l}0.173^{*} \\
(0.093)\end{array}$ \\
\hline & & $\mathrm{N}$ & & 1,931 & & 1,931 & & 997 & & 997 \\
\hline & Writing & & $\begin{array}{c}0.741^{* * *} \\
(0138)\end{array}$ & $0.127^{* *}$ & $0.171^{* * *}$ & $0.168 * * *$ & $0.636^{* * *}$ & 0.077 & 0.120 & 0.111 \\
\hline & Composition & $\mathrm{N}$ & $(0.138)$ & $\begin{array}{l}(0.052) \\
1,931 \\
\end{array}$ & $(0.064)$ & $\begin{array}{c}(0.062) \\
1,931 \\
\end{array}$ & & $\begin{array}{c}(0.054) \\
997\end{array}$ & & $\begin{array}{c}(0.086) \\
997\end{array}$ \\
\hline $\begin{array}{l}\text { Notes: } \\
\text { year of } \\
\text { schools } \\
\text { sibling } \\
\text { race, sp } \\
\text { high sch } \\
\text { across \& } \\
\text { * signifi }\end{array}$ & $\begin{array}{l}\text { le reports first s } \\
\text { y year of birth d } \\
\text { to)*(year of ap } \\
\text { or guaranteed a } \\
\text { lucation, limited } \\
\text { ts are given in } 1 \\
\text { the associated s } \\
10 \% ; * \text { * signific }\end{array}$ & & $\begin{array}{l}\text { d-form, and } \\
\text { ddle school a } \\
\text { id exclude st } \\
\text { olumns (4) a } \\
\text { ficiency, free } \\
\text { he table rep } \\
\text { ors allow for } \\
{ }^{*} \text { significan }\end{array}$ & $\begin{array}{l}\text { entary school } r \\
\text { vith sibling prio } \\
\text { port } 2 S L S \text { coef } \\
\text { d price lunch, a } \\
\text { ust standard er } \\
\text { clustering on }\end{array}$ & $\begin{array}{l}\text { ns pool } \\
\text { t regres } \\
\text { rom spe }\end{array}$ & $\begin{array}{l}\text { Itcomes and inc } \\
\text { lude dummies } \\
\text { ns that add dem } \\
\text { eraction. Elem } \\
\text { 10th grade scl } \\
\text { nt identifier. S }\end{array}$ & $\begin{array}{l}\text { cmesice) } \\
\text { che (ye } \\
\text { controls, } \\
\text { hool tests } \\
\text { igh school. } \\
\text { errors are r }\end{array}$ & $\begin{array}{l}\text { aseline demograp } \\
\text { el. Charter regres } \\
\text { plication)*(walk } \\
\text { clude dummies fo } \\
\text { h in 3rd and } 4 \text { th } \mathrm{g} \\
\text { he middle and ele } \\
\text { in parentheses. }\end{array}$ & $\begin{array}{l}\text { acteristics. } \\
\text { clude dum } \\
\text { tus) and ex } \\
\text { e, black, hi } \\
\text { iddle schoc } \\
\text { y school re }\end{array}$ & $\begin{array}{l}\text { essions include } \\
\text { or (combination of } \\
\text { students with } \\
\text { a asian, other } \\
\text { are given in } 6 \text { th, } \\
\text { ons pool students }\end{array}$ \\
\hline
\end{tabular}


Table 5: Lottery Results, Robustness Checks

\begin{tabular}{|c|c|c|c|c|c|c|c|c|c|c|}
\hline \multirow[b]{2}{*}{ Level } & \multirow[b]{2}{*}{ Subject } & \multicolumn{5}{|c|}{ Charter Lotteries } & \multicolumn{4}{|c|}{ Pilot Lotteries } \\
\hline & & & $\begin{array}{c}\text { Demo controls } \\
\text { (1) } \\
\end{array}$ & $\begin{array}{c}\text { Demo \& baseline } \\
\text { score controls } \\
(2)\end{array}$ & $\begin{array}{l}\text { Overidentified } \\
\text { model, demo } \\
\text { controls } \\
\text { (3) }\end{array}$ & $\begin{array}{l}\text { High school w/HCA } \\
\text { as pilot, demo } \\
\text { controls } \\
\text { (4) }\end{array}$ & $\begin{array}{c}\text { Demo controls } \\
\text { (5) } \\
\end{array}$ & $\begin{array}{c}\text { Demo \& baseline } \\
\text { score controls } \\
(6)\end{array}$ & $\begin{array}{c}\text { No K-8 pilot } \\
\text { applicants, demo } \\
\text { controls } \\
(7)\end{array}$ & $\begin{array}{l}\text { High school w/HCA } \\
\text { as pilot, demo } \\
\text { controls } \\
(8)\end{array}$ \\
\hline \multicolumn{11}{|c|}{ Middle School } \\
\hline \multirow{3}{*}{\multicolumn{2}{|c|}{ ELA }} & & $0.149 * * *$ & $0.144^{* * *}$ & $0.134 * * *$ & - & 0.006 & -0.035 & -0.079 & - \\
\hline & & & $(0.052)$ & $(0.044)$ & $(0.051)$ & & $(0.043)$ & $(0.112)$ & $(0.110)$ & \\
\hline & & $\mathrm{N}$ & 2,416 & 2,365 & 2,416 & & 3,390 & 2,414 & 2,645 & \\
\hline \multirow{3}{*}{\multicolumn{2}{|c|}{ Math }} & & $0.405^{* * *}$ & $0.386 * * *$ & $0.370 * * *$ & - & -0.059 & $-0.251 * *$ & $-0.233^{* *}$ & - \\
\hline & & & $(0.066)$ & $(0.054)$ & $(0.061)$ & & $(0.048)$ & $(0.106)$ & $(0.119)$ & \\
\hline & & $\mathrm{N}$ & 2,582 & 2,528 & 2,582 & & 3,851 & 2,733 & 3,075 & \\
\hline \multicolumn{11}{|c|}{ High School } \\
\hline \multirow{3}{*}{\multicolumn{2}{|c|}{ ELA }} & & $0.187^{* * *}$ & $0.186 * * *$ & $0.162 * * *$ & 0.112 & 0.007 & -0.053 & - & $0.111^{*}$ \\
\hline & & & $(0.055)$ & $(0.049)$ & $(0.053)$ & $(0.076)$ & $(0.073)$ & $(0.059)$ & & $(0.065)$ \\
\hline & & $\mathrm{N}$ & 1,947 & 1,629 & 1,947 & 1,683 & 1,007 & 949 & & 1,367 \\
\hline \multirow{3}{*}{\multicolumn{2}{|c|}{ Math }} & & $0.274 * * *$ & $0.226 * *$ & $0.251 * * *$ & $0.303^{* *}$ & -0.011 & 0.007 & - & 0.086 \\
\hline & & & $(0.071)$ & $(0.060)$ & $(0.065)$ & $(0.084)$ & $(0.101)$ & $(0.070)$ & & $(0.077)$ \\
\hline & & $\mathrm{N}$ & 1,929 & 1,892 & 1,929 & 1,664 & 996 & 983 & & 1,355 \\
\hline \multirow{3}{*}{\multicolumn{2}{|c|}{ Writing Topic }} & & $0.267 * * *$ & $0.281 * *$ & $0.248 * * *$ & $0.225^{* *}$ & $0.173^{*}$ & $0.151^{*}$ & - & $0.214 * *$ \\
\hline & & & $(0.078)$ & $(0.083)$ & $(0.070)$ & $(0.112)$ & $(0.093)$ & $(0.089)$ & & $(0.075)$ \\
\hline & & $\mathrm{N}$ & 1,931 & 1,616 & 1,931 & 1,670 & 997 & 934 & & 1,354 \\
\hline & Writing & & $0.168 * * *$ & $0.132^{* *}$ & $0.146^{* * *}$ & $0.156^{*}$ & 0.111 & 0.097 & - & $0.131 * *$ \\
\hline & \multirow[t]{2}{*}{ Composition } & & $(0.062)$ & $(0.059)$ & $(0.055)$ & $(0.089)$ & $(0.086)$ & $(0.080)$ & & $(0.065)$ \\
\hline & & $\mathrm{N}$ & 1,931 & 1,616 & 1,931 & 1,670 & 997 & 934 & & 1,354 \\
\hline
\end{tabular}


Table 6: Attrition

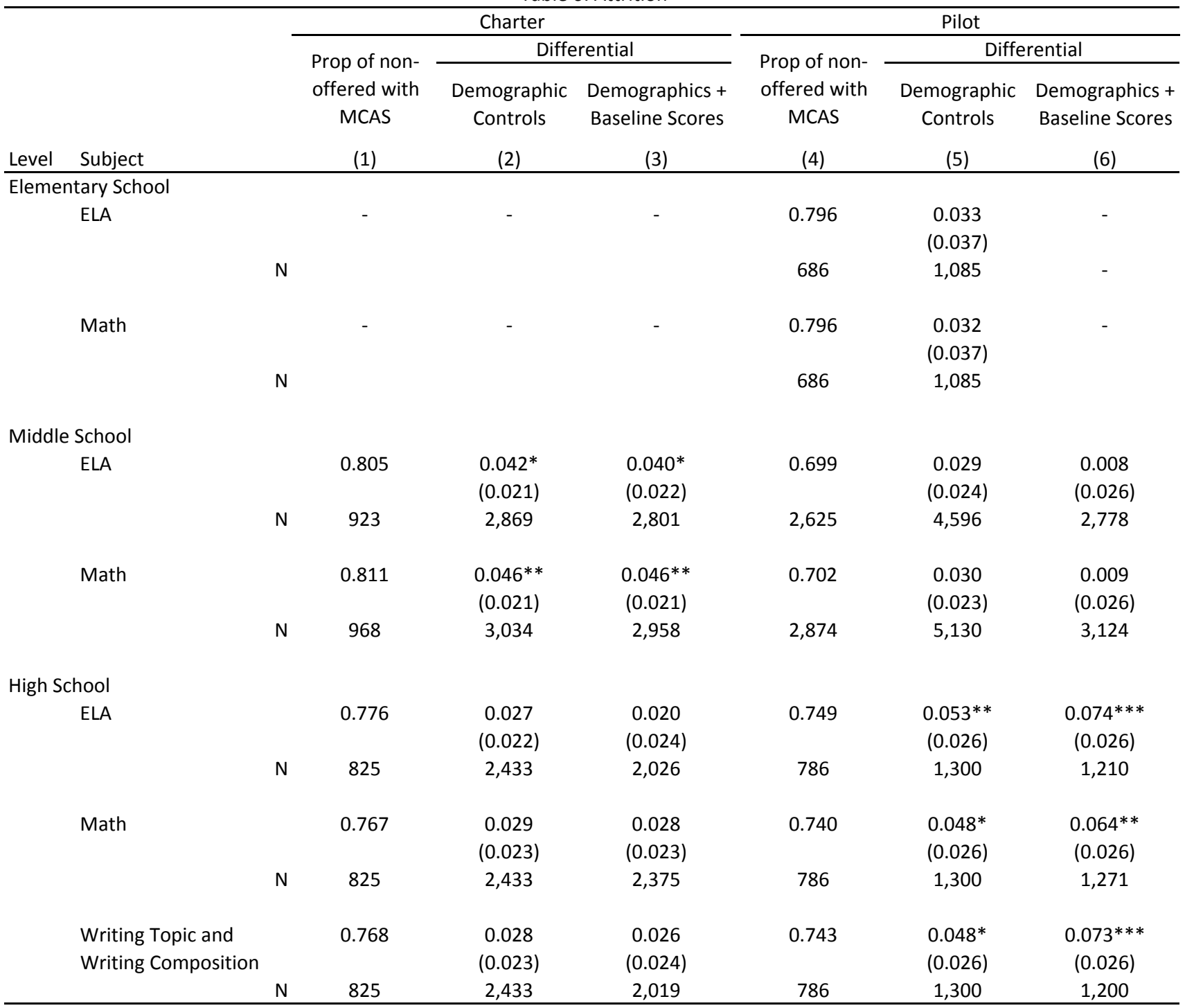

Notes: This table reports effects of lottery offers on a dummy variable that indicates when the outcome test score is non-missing. The specification is the same as that used to construct the estimates in Table 4. The sample in this case includes all students in the baseline-demographics universe and not just those with test scores. Standard errors, in parentheses, are clustered as described in the Table 4 notes

* significant at $10 \%{ }^{* *}$ significant at $5 \% ;{ }^{* * *}$ significant at $1 \%$ 
Table 7: Characteristics of Treated and Non-treated Schools for Compliers

\begin{tabular}{|c|c|c|c|c|c|c|c|c|}
\hline \multirow[b]{3}{*}{ School Characteristic } & \multicolumn{4}{|c|}{ Middle Schools } & \multicolumn{4}{|c|}{ High Schools } \\
\hline & \multicolumn{2}{|c|}{ Charter } & \multicolumn{2}{|c|}{ Pilot } & \multicolumn{2}{|c|}{ Charter } & \multicolumn{2}{|c|}{ Pilot } \\
\hline & $\begin{array}{c}\text { Non-Treated } \\
\text { (1) }\end{array}$ & $\begin{array}{c}\text { Treated } \\
\text { (2) }\end{array}$ & $\begin{array}{c}\text { Non-Treated } \\
\text { (3) }\end{array}$ & $\begin{array}{l}\text { Treated } \\
\text { (4) }\end{array}$ & $\begin{array}{c}\text { Non-Treated } \\
\text { (5) }\end{array}$ & $\begin{array}{l}\text { Treated } \\
\text { (6) }\end{array}$ & $\begin{array}{c}\text { Non-Treated } \\
\text { (7) }\end{array}$ & $\begin{array}{c}\text { Treated } \\
(8)\end{array}$ \\
\hline Fraction female & 0.464 & 0.545 & 0.465 & 0.477 & 0.494 & 0.652 & 0.473 & 0.406 \\
\hline Fraction black & 0.469 & 0.361 & 0.455 & 0.361 & 0.547 & 0.652 & 0.544 & 0.507 \\
\hline Fraction hispanic & 0.273 & 0.192 & 0.371 & 0.220 & 0.322 & 0.242 & 0.256 & 0.254 \\
\hline Fraction with limited English proficiency & 0.123 & -0.002 & 0.109 & 0.103 & 0.147 & 0.001 & 0.110 & 0.021 \\
\hline Fraction special ed & 0.227 & 0.103 & 0.267 & 0.186 & 0.188 & 0.089 & 0.194 & 0.143 \\
\hline Fraction free or reduced price lunch & 0.767 & 0.501 & 0.786 & 0.762 & 0.668 & 0.683 & 0.631 & 0.502 \\
\hline Fraction with first language not English & 0.310 & 0.143 & 0.390 & 0.382 & 0.368 & 0.229 & 0.346 & 0.315 \\
\hline Mean baseline ELA MCAS score & 0.110 & 0.353 & -0.043 & 0.262 & -0.211 & 0.202 & -0.168 & 0.039 \\
\hline Mean baseline Math MCAS score & 0.098 & 0.380 & -0.019 & 0.293 & -0.385 & 0.050 & -0.276 & -0.078 \\
\hline $\begin{array}{l}\text { Fraction of teachers licensed to teach } \\
\text { assignment }\end{array}$ & 0.904 & 0.496 & 0.889 & 0.857 & 0.842 & 0.776 & 0.864 & 0.898 \\
\hline Student/teacher ratio & 12.680 & 10.605 & 12.639 & 13.084 & 14.644 & 13.372 & 14.221 & 14.786 \\
\hline
\end{tabular}

Notes: This table reports mean treated and non-treated characteristics for compliers in the charter and pilot lotteries. The non-treated means are produced by

estimating models of the form: $X_{i}\left(1-D_{i}\right)=\lambda_{0 c}+\alpha_{0 c}\left(1-D_{i}\right)+\xi_{0 i}$, where $X_{i}$ is the school characteristic of interest observed at the school actually attended by each student in the year immediately after the lottery, $D_{i}$ is a dummy for whether the student attended charter/pilot in this year, $\lambda_{\text {oc }}$ represents controls (risk set dummies), and (1- $\left.D_{i}\right)$ is

instrumented using the lottery win/loss dummy. The IV estimate of $\alpha_{0 c}$ gives an estimate of the mean of $X$ for the compliers in the non-treated state. The treated means are produced by estimating models of the form $X_{i} D_{i}=\lambda_{1 c}+\alpha_{1 c} D_{i}+\xi_{1 i}$, where $D$ is instrumented by the lottery win/loss dummy. The IV estimate of $\alpha$ ic gives an estimate of the mean of $X$ for the compliers in the treated state. 
Table 8: Interaction Models

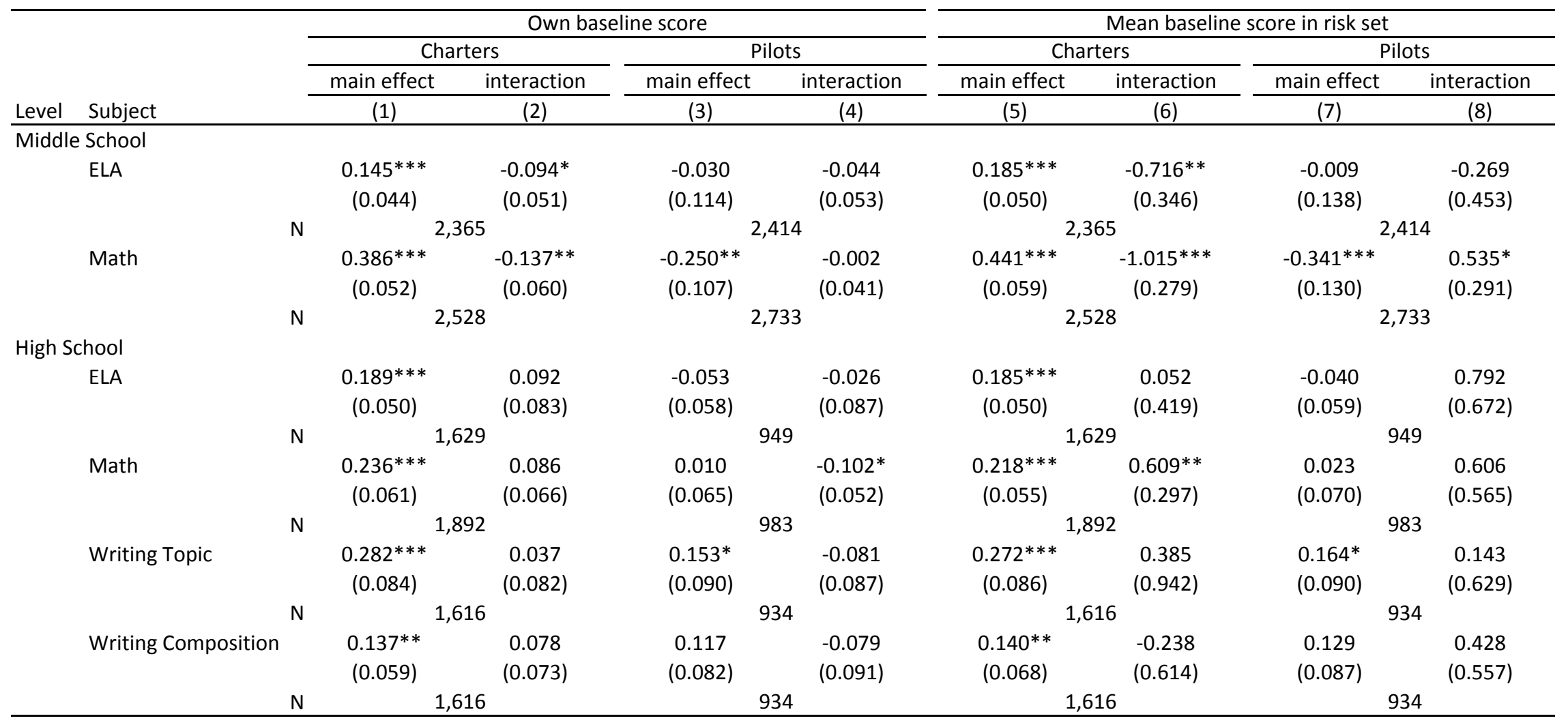

Notes: This table shows results results analogous to those reported in the 2 SLS lottery results in Table 4 , but the specifications include interaction terms. The models estimated are of the form: $y_{i g t}=\alpha_{t}+\beta_{g}+\sum \delta_{j} d_{i j}+\gamma X_{i}+\rho_{0} S_{i g t}+\rho_{1} A_{i}\left(S_{i g t}-S_{g}\right)+\varepsilon_{\text {igt }}$, where $y_{\text {igt }}$ is the outcome of interest for student i in grade $g$ in year $t$, $S_{\text {igt }}$ is years spent in charter (or Pilot), $A_{i}$ is own baseline test score or mean baseline score in the risk set, the $d_{i j}$ are risk set dummies, $X_{i}$ is a vector of controls, and $s_{g}$ is the average score in the sample so that the main effects $\rho_{0}$ are at the mean. $X_{i}$ includes year of birth dummies, year of test dummies, demographic controls, and an own baseline score main effect. Standard errors, in parentheses, are clustered as described in the Table 4 notes.

${ }^{*}$ significant at $10 \%$; ${ }^{*}$ significant at $5 \%$; ${ }^{* *}$ significant at $1 \%$ 
Table 9: Observational Analysis for Charter and Pilot

\begin{tabular}{|c|c|c|c|c|c|}
\hline \multirow{2}{*}{ Level } & \multirow[b]{2}{*}{ Subject } & \multicolumn{2}{|c|}{ Demographics } & \multicolumn{2}{|c|}{ Demographics \& Baseline Scores } \\
\hline & & $\begin{array}{l}\text { Charter } \\
\text { (1) }\end{array}$ & $\begin{array}{l}\text { Pilot } \\
\text { (2) }\end{array}$ & $\begin{array}{c}\text { Charter } \\
\text { (3) }\end{array}$ & $\begin{array}{l}\text { Pilot } \\
\text { (4) }\end{array}$ \\
\hline \multicolumn{6}{|c|}{ Elementary School } \\
\hline & $\mathrm{ELA}^{1}$ & $\begin{array}{c}0.055^{* * *} \\
(0.017)\end{array}$ & $\begin{array}{c}0.015 \\
(0.020)\end{array}$ & - & - \\
\hline & $\mathrm{N}$ & \multicolumn{2}{|c|}{20,058} & & \\
\hline & $\mathrm{R}^{2}$ & \multicolumn{2}{|c|}{0.134} & & \\
\hline & Math $^{2}$ & $\begin{array}{c}0.038 \\
(0.023)\end{array}$ & $\begin{array}{c}0.024 \\
(0.023)\end{array}$ & - & - \\
\hline & $\mathrm{N}$ & \multicolumn{2}{|c|}{17,356} & & \\
\hline & $\mathrm{R}^{2}$ & \multicolumn{2}{|c|}{0.131} & & \\
\hline \multicolumn{6}{|c|}{ Middle School } \\
\hline & $\mathrm{ELA}^{3}$ & $\begin{array}{c}0.116^{* * *} \\
(0.014)\end{array}$ & $\begin{array}{c}-0.072 * * * \\
(0.014)\end{array}$ & $\begin{array}{c}0.104^{* * *} \\
(0.012)\end{array}$ & $\begin{array}{c}-0.078 * * * \\
(0.011)\end{array}$ \\
\hline & $\mathrm{N}$ & \multicolumn{2}{|c|}{34,301} & \multicolumn{2}{|c|}{31,620} \\
\hline & $\mathrm{R}^{2}$ & \multicolumn{2}{|c|}{0.339} & \multicolumn{2}{|c|}{0.538} \\
\hline & Math $^{4}$ & $\begin{array}{c}0.176^{* * *} \\
(0.020)\end{array}$ & $\begin{array}{c}-0.096 * * * \\
(0.017)\end{array}$ & $\begin{array}{c}0.180 * * * \\
(0.018)\end{array}$ & $\begin{array}{c}-0.100 * * * \\
(0.013)\end{array}$ \\
\hline & $\mathrm{N}$ & \multicolumn{2}{|c|}{38,583} & \multicolumn{2}{|c|}{35,764} \\
\hline & $\mathrm{R}^{2}$ & \multicolumn{2}{|c|}{0.350} & \multicolumn{2}{|c|}{0.576} \\
\hline \multicolumn{6}{|c|}{ High School } \\
\hline & $\mathrm{ELA}^{5}$ & $\begin{array}{c}0.228 * * * \\
(0.020)\end{array}$ & $\begin{array}{c}0.155^{* * *} \\
(0.018)\end{array}$ & $\begin{array}{c}0.166 * * * \\
(0.018)\end{array}$ & $\begin{array}{c}0.094^{* * *} \\
(0.016)\end{array}$ \\
\hline & $\mathrm{N}$ & \multicolumn{2}{|c|}{16,609} & \multicolumn{2}{|c|}{12,347} \\
\hline & $\mathrm{R}^{2}$ & \multicolumn{2}{|c|}{0.487} & \multicolumn{2}{|c|}{0.623} \\
\hline & Math $^{6}$ & $\begin{array}{c}0.247^{* * *} \\
(0.040)\end{array}$ & $\begin{array}{c}0.126 * * * \\
(0.026)\end{array}$ & $\begin{array}{c}0.151^{* * *} \\
(0.031)\end{array}$ & $\begin{array}{c}0.052 * * \\
(0.023)\end{array}$ \\
\hline & $\mathrm{N}$ & \multicolumn{2}{|c|}{16,350} & \multicolumn{2}{|c|}{15,868} \\
\hline & $\mathrm{R}^{2}$ & \multicolumn{2}{|c|}{0.509} & \multicolumn{2}{|c|}{0.700} \\
\hline & Writing Topic ${ }^{7}$ & $\begin{array}{c}0.228^{* * *} \\
(0.028)\end{array}$ & $\begin{array}{c}0.154^{* * *} \\
(0.023)\end{array}$ & $\begin{array}{c}0.206 * * * \\
(0.031)\end{array}$ & $\begin{array}{c}0.141^{* * *} \\
(0.024)\end{array}$ \\
\hline & $\mathrm{N}$ & \multicolumn{2}{|c|}{16,289} & \multicolumn{2}{|c|}{12,181} \\
\hline & $\mathrm{R}^{2}$ & \multicolumn{2}{|c|}{0.308} & & \\
\hline & Writing Composition ${ }^{8}$ & $\begin{array}{c}0.204 * * * \\
(0.021)\end{array}$ & $\begin{array}{c}0.148 * * * \\
(0.019)\end{array}$ & $\begin{array}{c}0.178 * * * \\
(0.022)\end{array}$ & $\begin{array}{c}0.129 * * * \\
(0.018)\end{array}$ \\
\hline & $\mathrm{N}$ & & & & \\
\hline & $\mathrm{R}^{2}$ & & & & \\
\hline
\end{tabular}

Notes: This table reports OLS estimates of the effects of time spent in schools of various types. The excluded category is traditional BPS schools. The sample restricted to students with baseline demographic characteristics. Demographics include female, black, hispanic, asian, other race, special education, limited english proficiency, free/reduced price lunch, and a female*minority dummy. Regressions also include year of test and year of birth dummies. Middle school and elementary school regressions pool grade outcomes and include dummies for grade level. Regressions use robust standard errors and are clustered as in Table 4. Standard errors are reported in parentheses.

${ }^{*}$ significant at $10 \% ;{ }^{* *}$ significant at $5 \%$; ${ }^{* * *}$ significant at $1 \%$

1. Elementary school ELA is for Grade 3 (2005-08) and Grade 4 (2005-08).

2. Elementary school Math is for Grade 3 (2005-08) and Grade 4 (2005-08).

3. Middle school ELA is for Grade 6 (2005-08), Grade 7 (2005-08), and Grade 8 (2005-08)

4. Middle school Math is for Grade 6 (2004-08), Grade 7 (2005-08), and Grade 8 (2006-08)

5. High school ELA is for Grade 10 (2004-08).

6. High school Math is for Grade 10 (2004-08).

7. High school Writing Topic is for Grade 10 (2004-08).

8. High school Writing Composition is for Grade 10 (2004-08). 
Table 10: Estimates in and Out of the Lottery Sample

\begin{tabular}{|c|c|c|c|c|c|c|c|c|c|}
\hline \multirow[b]{3}{*}{ Level } & \multirow[b]{3}{*}{ Subject } & \multicolumn{4}{|c|}{ Charters } & \multicolumn{4}{|c|}{ Pilots } \\
\hline & & \multicolumn{2}{|c|}{ Lottery } & \multicolumn{2}{|c|}{ Observational } & \multicolumn{2}{|c|}{ Lottery } & \multicolumn{2}{|c|}{ Observational } \\
\hline & & $\begin{array}{c}\text { With } \\
\text { Demographics } \\
\text { (1) }\end{array}$ & $\begin{array}{c}\text { With Baseline } \\
\text { Scores } \\
(2) \\
\end{array}$ & $\begin{array}{c}\text { In Lottery } \\
\text { Sample } \\
(3)\end{array}$ & $\begin{array}{l}\text { Not in Lottery } \\
\text { Sample } \\
\text { (4) }\end{array}$ & $\begin{array}{c}\text { With } \\
\text { Demographics } \\
(5)\end{array}$ & $\begin{array}{c}\text { With Baseline } \\
\text { Scores } \\
(6)\end{array}$ & $\begin{array}{l}\text { In Lottery } \\
\text { Sample } \\
(7)\end{array}$ & $\begin{array}{c}\text { Not in Lottery } \\
\text { Sample } \\
(8)\end{array}$ \\
\hline \multicolumn{10}{|c|}{ Elementary School } \\
\hline & \multirow[t]{2}{*}{ ELA } & \multirow[t]{2}{*}{ - } & \multirow[t]{2}{*}{-} & \multirow[t]{2}{*}{-} & $\begin{array}{c}0.055^{* * *} \\
(0.018)\end{array}$ & $\begin{array}{c}0.064^{* * *} \\
(0.024)\end{array}$ & \multirow[t]{2}{*}{-} & $\begin{array}{l}0.051^{*} \\
(0.026)\end{array}$ & \multirow{2}{*}{$\begin{aligned} & -0.033 \\
& (0.025)\end{aligned}$} \\
\hline & & & & & 20,058 & 876 & & & \\
\hline & \multirow[t]{2}{*}{ Math } & \multirow[b]{2}{*}{ N } & \multirow[t]{2}{*}{-} & \multirow[t]{2}{*}{-} & $\begin{array}{c}0.037 \\
(0.023)\end{array}$ & $\begin{array}{c}0.060^{* *} \\
(0.026)\end{array}$ & \multirow[t]{2}{*}{-} & $\begin{array}{c}0.079 * * * \\
(0.028)\end{array}$ & \multirow{2}{*}{$56^{-0.059^{*}}(032)$} \\
\hline & & & & & 17,356 & 874 & & & \\
\hline \multicolumn{10}{|c|}{ Middle School } \\
\hline & \multirow[t]{2}{*}{ ELA } & $\begin{array}{c}0.149 * * * \\
(0.052)\end{array}$ & $\begin{array}{c}0.144 * * * \\
(0.044)\end{array}$ & $\begin{array}{c}0.158^{* * *} \\
(0.017)\end{array}$ & $\begin{array}{c}0.082^{* * *} \\
(0.014)\end{array}$ & $\begin{array}{c}0.006 \\
(0.043)\end{array}$ & $\begin{array}{l}-0.035 \\
(0.112)\end{array}$ & $\begin{array}{c}-0.076^{* * *} \\
(0.015)\end{array}$ & $\begin{array}{c}-0.079 * * * \\
(0.016)\end{array}$ \\
\hline & & 2,416 & 2,365 & \multicolumn{2}{|c|}{31,620} & 3,390 & 2,414 & \multicolumn{2}{|c|}{31,620} \\
\hline & \multirow[t]{2}{*}{ Math } & $\begin{array}{c}0.405^{* * *} \\
(0.066)\end{array}$ & $\begin{array}{c}0.386 * * * \\
(0.054)\end{array}$ & $\begin{array}{c}0.312^{* * *} \\
(0.028)\end{array}$ & $\begin{array}{c}0.129 * * * \\
(0.020)\end{array}$ & $\begin{array}{l}-0.059 \\
(0.048)\end{array}$ & $\begin{array}{c}-0.251 * * \\
(0.106)\end{array}$ & $\begin{array}{c}-0.116^{* * *} \\
(0.015)\end{array}$ & $\begin{array}{c}-0.078 * * * \\
(0.019)\end{array}$ \\
\hline & & 2,582 & 2,528 & \multicolumn{2}{|c|}{35,764} & 3,851 & 2,733 & \multicolumn{2}{|c|}{35,764} \\
\hline \multicolumn{10}{|c|}{ High School } \\
\hline & \multirow[t]{2}{*}{ ELA } & $\begin{array}{c}0.187^{* * *} \\
(0.055)\end{array}$ & $\begin{array}{c}0.186 * * * \\
(0.049)\end{array}$ & $\begin{array}{c}0.188^{* * *} \\
(0.023)\end{array}$ & $\begin{array}{c}0.134^{* * *} \\
(0.022)\end{array}$ & $\begin{array}{c}0.007 \\
(0.073)\end{array}$ & $\begin{array}{l}-0.053 \\
(0.059)\end{array}$ & $\begin{array}{c}0.141 * * * \\
(0.018)\end{array}$ & $\begin{array}{c}0.077^{* * *} \\
(0.017)\end{array}$ \\
\hline & & 1,947 & 1,629 & \multicolumn{2}{|c|}{12,347} & 1,007 & 949 & \multicolumn{2}{|c|}{12,347} \\
\hline & Math & $\begin{array}{c}0.274 * * * \\
(0.071)\end{array}$ & $\begin{array}{c}0.226 * * \\
(0.060)\end{array}$ & $\begin{array}{c}0.158^{* * *} \\
(0.045)\end{array}$ & $\begin{array}{c}0.140 * * * \\
(0.032)\end{array}$ & $\begin{array}{l}-0.011 \\
(0.101)\end{array}$ & $\begin{array}{c}0.007 \\
(0.070)\end{array}$ & $\begin{array}{c}0.139 * * * \\
(0.036)\end{array}$ & $\begin{array}{c}0.024 \\
(0.023)\end{array}$ \\
\hline & & 1,929 & 1,892 & & 368 & 996 & 983 & & 368 \\
\hline & Writing Topic & $\begin{array}{c}0.267 * * * \\
(0.078)\end{array}$ & $\begin{array}{c}0.281^{* *} \\
(0.083)\end{array}$ & $\begin{array}{c}0.253^{* * *} \\
(0.041)\end{array}$ & $\begin{array}{c}0.136 * * * \\
(0.032)\end{array}$ & $\begin{array}{l}0.173 * \\
(0.093)\end{array}$ & $\begin{array}{l}0.151^{*} \\
(0.089)\end{array}$ & $\begin{array}{c}0.242 * * * \\
(0.019)\end{array}$ & $\begin{array}{c}0.103^{* * *} \\
(0.025)\end{array}$ \\
\hline & & 1,931 & 1,616 & & 181 & 997 & 934 & & 181 \\
\hline & $\begin{array}{l}\text { Writing } \\
\text { Composition }\end{array}$ & $\begin{array}{c}0.168 * * * \\
(0.062)\end{array}$ & $\begin{array}{c}0.132^{* *} \\
(0.059)\end{array}$ & $\begin{array}{c}0.207^{* * *} \\
(0.029)\end{array}$ & $\begin{array}{c}0.134 * * * \\
(0.024)\end{array}$ & $\begin{array}{c}0.111 \\
(0.086)\end{array}$ & $\begin{array}{c}0.097 \\
(0.080)\end{array}$ & $\begin{array}{c}0.195^{* * *} \\
(0.021)\end{array}$ & $\begin{array}{c}0.104^{* * *} \\
(0.018)\end{array}$ \\
\hline & & 1,931 & 1,616 & & & 997 & 934 & & 181 \\
\hline $\begin{array}{l}\text { are clus } \\
* \text { signifi }\end{array}$ & $\begin{array}{l}\text { s (1) and (5) of } \\
\text { rvational mode } \\
\text { models also in } \\
\text { ssion. As in Tab } \\
\text { s described in th } \\
10 \% \text {; }{ }^{* *} \text { signific }\end{array}$ & $\begin{array}{l}\text { f this table report } 2 \mathrm{SLSC} \\
\text { els include separate var } \\
\text { nclude the same covaria } \\
\text { able } 9 \text {, observational mc } \\
\text { the Table } 4 \text { notes. } \\
\text { icant at } 5 \% \text {; }{ }^{* * *} \text { signific }\end{array}$ & $\begin{array}{l}\text { coefficients from Tak } \\
\text { riables for years in lo } \\
\text { ates as used to const } \\
\text { odels restrict the sar } \\
\text { ant at } 1 \%\end{array}$ & Columns (2) & $\begin{array}{l}\text { (6) report } 2 S L S \text { co } \\
\text { ols, lottery sampl } \\
\text { able } 9 \text {. For a giver } \\
\text { vere in a BPS or Bo }\end{array}$ & $\begin{array}{l}\text { its from Table 5. } \\
\text { er schools, non-lo } \\
\text { l level and test, cc } \\
\text { narter school in th }\end{array}$ & $\begin{array}{l}\text { ese models inclu } \\
\text { ery sample pilot } \\
\text { umns (3), (4), (7) } \\
\text { year of the relev }\end{array}$ & $\begin{array}{l}\text { ographic and } \\
\text { and non-lotte } \\
\text { report coeffic } \\
\text { Standard er }\end{array}$ & $\begin{array}{l}\text { eline test score } \\
\text { sample charter } \\
\text { t estimates from } \\
\text {, in parentheses, }\end{array}$ \\
\hline
\end{tabular}




\section{VIV Estimates of the Middle School Math Effect}

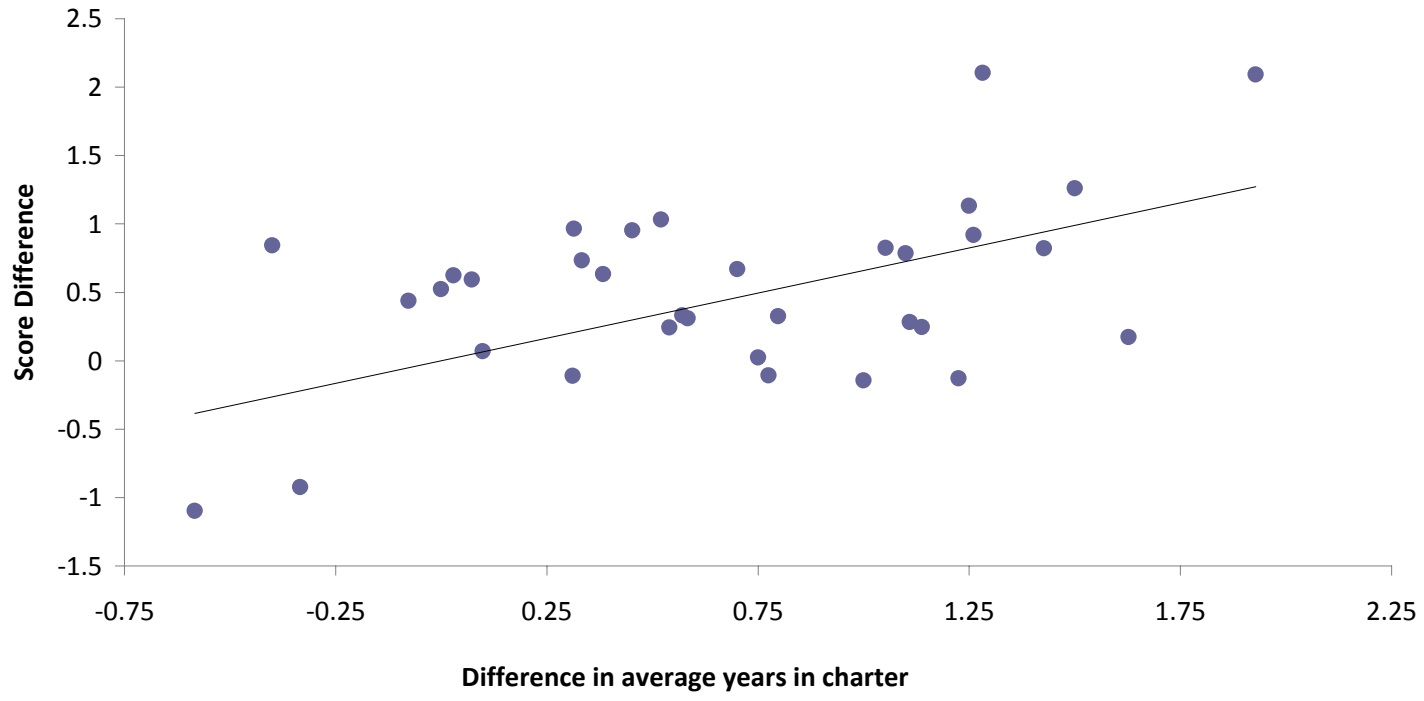

A. Charter Schools

\section{VIV Estimates of the Middle School Math Effect}

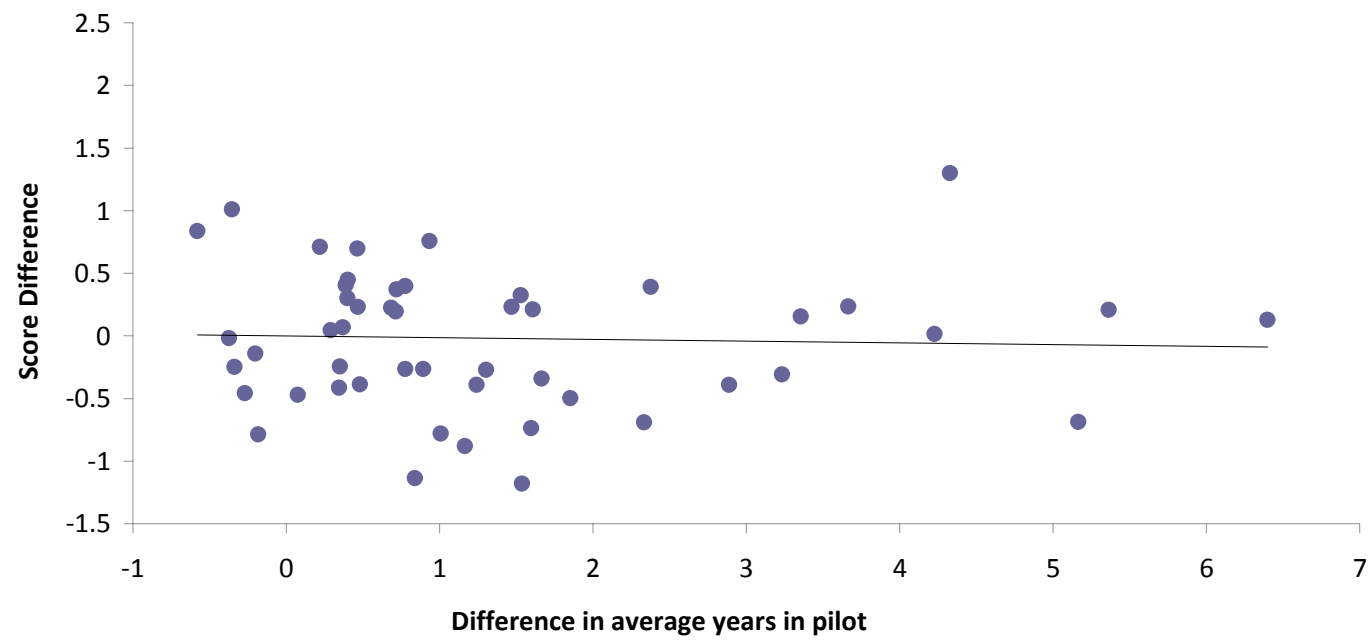

B. Pilot Schools

Figure 1. This figure plots treatment-control differences in test score means against treatment-control differences in years in charter (Panel A) or pilot (Panel B). The unit of observation is a charter or pilot application risk set ( $\mathrm{N}=34$ for charters and $\mathrm{N}=51$ for pilots). The charter slope (unweighted) is .66 , and the corresponding 2SLS estimate is .44. The pilot slope (unweighted) is -.006 , while the corresponding 2SLS estimate is -.007. The pilot graph is produced after dropping one small imbalanced risk set. 


\section{Data Appendix}

\section{Data Sources}

The data for this study come from four sources: the BPS assignment system, lottery records from individual charter schools, and two state-wide datasets, the SIMS and MCAS files. The BPS assignment data are documented in Abdulkadiroğlu, Pathak, Roth and Sönmez (2006). Lottery coverage is documented below and in Table A1. Following the discussion of lottery data, we describe the state data sets and our matching process in detail.

\section{Lottery Sample Coverage}

Charter School Lotteries

- Of the four charters that enroll elementary school students, three had no usable lottery data. One K-8 school contributes to the middle school sample but is not used in the elementary school analysis because it added elementary grades only in 2006.

- Of the 11 charters that enroll middle school students, five contribute to the lottery analysis: Academy of the Pacific Rim, Boston Collegiate, Boston Preparatory, Edward Brooke and Roxbury Preparatory. Two non-included schools closed before or while the study was under way. Lottery data from four other schools were unavailable, either because they were not archived or lost.

- Of the eight (non-alternative) charter schools that enroll high school students, four contribute to the lottery analysis: City on a Hill, Codman Academy, MATCH, and Health Careers Academy (a Horace Mann Charter). Two non-included schools closed before or while the study was under way. Two schools do not admit via lottery in grade nine but rather admit students in grade five; they contribute to the middle school analysis.

\section{Pilot School Lotteries}

- Of the seven pilot schools that enroll elementary school students, five were over-subscribed in our sample window and contribute to the lottery sample: Lyndon, Mason Elementary, Mission Hill, Orchard Gardens, and Young Achievers.

- Of seven pilot middle schools admitting 6th graders, six were over-subscribed and contribute to our lottery sample: Harbor School, Josiah Quincy, Lilla G. Frederick, Lyndon, Mission Hill, Orchard Gardens. We also have middle school scores from three K-8 pilot schools: Lyndon, 
Mission Hill, and Young Achievers. A fourth K-8 pilot began enrolling kindergartners too late to contribute middle school outcomes.

- Of the six (non-alternative) 9-12 pilot high schools, two use lotteries and contribute to the lottery sample: Another Course to College, and TechBoston Academy. One 6-12 pilot was not oversubscribed. A single alternative high school that serves an older population was omitted from the study.

The applicant cohorts contributed by each school are detailed in Appendix Table A1.

\section{State Data}

The first state dataset is the Massachusetts Students Information Management System (SIMS). This contains snapshots of all students in public school in Massachusetts in October and at the end of the school year. The SIMS file includes demographic information on students, their current school, residence, and days of attendance. We work with the SIMS files for the 2001-2002 through the 20072008 school years. Schools are classified as pilot schools, charter schools, public schools, exam schools, and alternative/special education schools using a grade-specific algorithm described below. The second state-wide dataset is the Massachusetts Comprehensive Assessment System (MCAS) database. The MCAS files have raw test scores for Math, English Language Arts (ELA), and Writing for grades 3-8 and grade 10 from spring 2002-2007. We standardized MCAS scores by subject, grade, and year to a combined BPS and Boston charter schools reference population. MCAS scores were merged to the SIMS file using unique student identifiers (the SASID). Students in the MCAS file but not in the SIMS file are excluded because they cannot be assigned to schools.

\section{Cohorts and Test Years Analyzed}

The cohorts and test years analyzed in this study are summarized in the table below. Baseline years are defined as the year a student attended 8th grade for the high school sample, the year a student attended 4th grade for the middle school sample, and the year a student attended kindergarten for the elementary school and K2-applicants-to-K-8-middle-school samples. There are no baseline test score for this last group of students, but we pulled demographics from the baseline years listed in the table. 


\begin{tabular}{lcccc}
\hline & $\begin{array}{c}\text { Elementary } \\
\text { school }\end{array}$ & $\begin{array}{c}\text { Middle (non-K2 } \\
\text { applicants) }\end{array}$ & $\begin{array}{c}\text { Middle (K2 } \\
\text { lottery applicants) }\end{array}$ & $\begin{array}{c}\text { High } \\
\text { school }\end{array}$ \\
\hline $\begin{array}{l}\text { Outcome } \\
\text { years }\end{array}$ & $\begin{array}{c}\text { Lottery application } \\
\text { Lottery application }\end{array}$ & $2003-2008$ & $2004-2008$ & $2004-2008$ \\
years & $2002-2004$ & $2002-2004$ & $2002-2007$ & $1997-2001$ \\
& Baseline & $2002-2005$ & $1997-2001$ & $2002-2006$ \\
$\begin{array}{l}\text { Baseline } \\
\text { years }\end{array}$ & $2002-2005$ & $2001-2006$ & $1998-2002$ & $2002-2006$ \\
\hline
\end{tabular}

Notes: All years refer to Spring. Baseline grades are kindergarten for elementary school and K2 middle school applicants, 4th grade for all other middle school students and 8th grade for high school students. The 2003 middle school outcome year is used only for 2002 pilot middle school 6th grade applicants, as we use BPS demographics for these students from 2001 and we do not have state demographics for 2001.

\section{Analysis Samples}

Three matched files constitute the extracts used for statistical analysis. The first (the charter lottery extract) was constructed by linking charter applicants to SIMS and MCAS data; the second (the pilot lottery extract) was constructed by linking students with a first-choice pilot in the BPS assignment mechanism to SIMS and MCAS records; and the third and largest (the observational extract) uses the SIMS and MCAS matched file without regard to charter and pilot application. Table A2 shows how these three extracts were constructed. All three extracts are limited to students enrolled in BPS or a Boston charter school as of the relevant baseline date.

\section{Classification of Schools}

We define pilot schools as those listed on the pilot school network website at http://www.ccebos.org/pilotschools/schools.html. We define charter schools as those schools identified as such by the Massachusetts Department of Elementary and Second Education website (http://www.profiles.doe.mass.edu). As discussed in the text, Health Careers Academy is a Horace Mann charter high school. Boston Day and Evening Charter, also a Horace Mann charter, serves over-age students. This school, along with Greater Egleston Community High School, a pilot school that also serves older students, was designated as an alternative/special education school rather than a charter or pilot and therefore omitted from our lottery analysis. 


\section{Placing Students at Schools}

In the Massachusetts State SIMS file, school designation is grade-specific. When a student repeats

grades, we kept the first school in grade. Students attending multiple schools in a given school year were assigned as follows:

- A student was assigned to a Boston charter or pilot school if any record for the grade shows attendance at a Boston charter or pilot.

- If a student attends multiple Boston charters or pilots, or both a Boston charter and pilot, the student was assigned to school for which the attendance duration is longest. Ties are broken randomly.

- Students attending multiple traditional BPS schools were assigned to the school of the longest attendance duration. Ties were broken randomly. 
Table A.1: Charter and Pilot School Study Participation

\begin{tabular}{|c|c|c|c|c|}
\hline & $\begin{array}{l}\text { Years in Lottery Study } \\
\text { (1) }\end{array}$ & $\begin{array}{c}\text { Years with Initial } \\
\text { Offer Data } \\
\text { (2) }\end{array}$ & $\begin{array}{c}\text { Grade Range } \\
\text { (3) }\end{array}$ & $\begin{array}{l}\text { Notes } \\
(4)\end{array}$ \\
\hline \multicolumn{5}{|c|}{ I. Elementary School (3rd and 4th grades) } \\
\hline \multicolumn{5}{|l|}{ Charter Schools } \\
\hline Boston Renaissance Charter Public School & $\mathrm{x}$ & $\mathrm{x}$ & $\mathrm{K}-6$ & School lottery data are unavailable for elementary school. \\
\hline Conservatory Lab Charter School & $\mathrm{x}$ & $\mathrm{x}$ & $\mathrm{K}-5$ & School lottery data are unavailable for elementary school. \\
\hline Edward Brooke Charter School & $\mathrm{x}$ & $\mathrm{x}$ & $\mathrm{K}-8$ & Became $\mathrm{K}-8$ in 2006 , so test scores are not used in elementary analyses. \\
\hline Neighborhood House Charter School & $\mathrm{x}$ & $\mathrm{x}$ & $\mathrm{K}-8$ & School lottery data are unavailable for elementary school. \\
\hline \multicolumn{5}{|l|}{ Pilot Schools } \\
\hline Gardner Elementary School & $\mathrm{x}$ & $\mathrm{x}$ & K-5 & All applicants in 2002-2004 are accepted. \\
\hline Lee Academy & $x$ & $\mathrm{x}$ & K-5 & New school in 2004, all applicants in 2004 are accepted. \\
\hline Lyndon K-8 School & 2002-2004 & $\mathrm{x}$ & $\mathrm{K}-8$ & \\
\hline Mason Elementary School & 2003-2004 & $\mathrm{x}$ & K-5 & All applicants in 2002 are accepted. \\
\hline Mission Hill School & 2002-2004 & $\mathrm{x}$ & $\mathrm{K}-8$ & \\
\hline Orchard Gardens K-8 School & 2003-2004 & $\mathrm{x}$ & $\mathrm{K}-8$ & No Kindergarten class in 2002 (new school). \\
\hline Young Achievers K-8 School & 2002-2004 & $\mathrm{x}$ & $\mathrm{K}-8$ & \\
\hline \multicolumn{5}{|c|}{ II. Middle School (6th, 7th, and 8th grades) } \\
\hline \multicolumn{5}{|l|}{ Charter Schools } \\
\hline Academy of the Pacific Rim Charter Public School & 2005-2007 & 2005-2007 & $5-12$ & Insufficient lottery records from 2002-2004. \\
\hline Boston Collegiate Charter School & 2002-2006 & 2002-2006 & $5-12$ & \\
\hline Boston Preparatory Charter Public School & 2005-2007 & 2005, 2007 & $6-10$ & All applicants in 2004 accepted. Initial offer only 2005, ever offer only 2006. \\
\hline Boston Renaissance Charter Public School & $x$ & $\mathrm{x}$ & $\mathrm{k}-6$ & School lottery data are unavailable. \\
\hline Edward Brooke Charter School & 2006 & $\mathrm{x}$ & $\mathrm{k}-8$ & Became K-8 in 2006. \\
\hline Excel Academy Charter School & $\mathrm{x}$ & $\mathrm{x}$ & $5-8$ & Insufficient lottery records. \\
\hline Frederick Douglass Charter School & $\mathrm{x}$ & $\mathrm{x}$ & $5-12$ & Closed. \\
\hline Neighborhood House Charter School & $\mathrm{x}$ & $\mathrm{x}$ & $\mathrm{K}-8$ & School lottery data are unavailable for elementary school. \\
\hline Roxbury Preparatory Charter School & 2002-2007 & $\mathrm{x}$ & 6-8 & Ever offer only 2002-2007. \\
\hline Smith Leadership Academy Charter Public School & $x$ & $\mathrm{x}$ & 6-8 & Insufficient admissions lottery records. \\
\hline Uphams Corner Charter School & $\mathrm{x}$ & $\mathrm{x}$ & $5-8$ & Insufficient admissions lottery records. Closed. \\
\hline \multicolumn{5}{|l|}{ Pilot Schools - 6th Grade Applicants } \\
\hline Harbor School & $2002,2006-2007$ & $\mathrm{x}$ & $6-8$ & All applicants in 2003-2005 are accepted. \\
\hline Josiah Quincy Upper School & 2004-2007 & $\mathrm{x}$ & $6-12$ & No Grade 6 class in 2002 and 2003 (new school). \\
\hline Lilla G. Frederick Pilot Middle School & 2004-2007 & $\mathrm{x}$ & $6-8$ & No Grade 6 class in 2002 and all Grade 6 applicants in 2003 are accepted. \\
\hline Lyndon K-8 School & 2004-2007 & $\mathrm{x}$ & $\mathrm{K}-8$ & All Grade 6 applicants in 2002 and 2003 guaranteed admission. \\
\hline Mission Hill School & 2002-2003, 2007 & $\mathrm{x}$ & $\mathrm{K}-8$ & All Grade 6 applicants in 2004-2006 guaranteed admission. \\
\hline Orchard Gardens K-8 School & 2003-2007 & $\mathrm{x}$ & $\mathrm{k}-8$ & No Grade 6 class in 2002 (new school). \\
\hline Young Achievers K-8 School & $\mathrm{x}$ & $\mathrm{x}$ & $\mathrm{k}-8$ & All Grade 6 applicants in 2002-2007 guaranteed admission. \\
\hline \multicolumn{5}{|l|}{ Pilot Schools - K2 applicants } \\
\hline Lyndon K-8 School & 1997-1998, 2000-2001 & $\mathrm{x}$ & $\mathrm{k}-8$ & All K2 applicants in 1999 were admitted. \\
\hline Mission Hill School & 1998-2001 & $\mathrm{x}$ & $\mathrm{K}-8$ & \\
\hline Orchard Gardens K-8 School & $x$ & $\mathrm{x}$ & $\mathrm{K}-8$ & No Kindergarten class before 2003 . \\
\hline Young Achievers K-8 School & 1999-2001 & $\mathrm{x}$ & $\mathrm{k}-8$ & Error in records 1998, all K2 applicants in 1997 guaranteed admission. \\
\hline \multicolumn{5}{|c|}{ III. High School (10th grade) } \\
\hline \multicolumn{5}{|l|}{ Charter Schools } \\
\hline Academy of the Pacific Rim Charter Public School & $\mathrm{x}$ & $\mathrm{x}$ & $5-12$ & No admissions lottery for students in Grade 9. \\
\hline Boston Collegiate Charter School & $\mathrm{x}$ & $\mathrm{x}$ & $5-12$ & No admissions lottery for students in Grade 9. \\
\hline City On A Hill Charter Public School & $2002,2004-2006$ & $2002,2004-2006$ & $9-12$ & Initial only for 2002 and 2004, records unclear in 2003. \\
\hline Codman Academy Charter Public School & 2004 & 2004 & $9-12$ & Initial offer data only for 2004. \\
\hline Frederick Douglass Charter School & $x$ & $\mathrm{x}$ & $5-12$ & Closed. \\
\hline MATCH Charter Public High School & 2002-2006 & 2002-2004 & $9-12$ & Ever offer only 2005-2006. \\
\hline Roxbury Charter High Public School & $\mathrm{x}$ & $\mathrm{x}$ & $9-12$ & Closed. \\
\hline \multicolumn{5}{|l|}{ Horace Mann Charter Schools } \\
\hline Boston Day and Even Academy Charter School & $\mathrm{x}$ & & 9-12, Alt & Included in observational study as alternative school. \\
\hline Health Careers Academy Charter School & 2003-2006 & 2003-2006 & $9-12$ & \\
\hline \multicolumn{5}{|l|}{ Pilot Schools } \\
\hline Greater Egleston Community High & $\mathrm{x}$ & $\mathrm{x}$ & 9-12, Alt & Included in observational study as alternative school. \\
\hline Another Course to College & 2003-2006 & $\mathrm{x}$ & $9-12$ & No Grade 9 class in 2002 (new school). \\
\hline Boston Arts Academy & $\mathrm{x}$ & $\mathrm{x}$ & $9-12$ & Selective admissions. \\
\hline Boston Community Leadership Academy & $\mathrm{x}$ & $\mathrm{x}$ & $9-12$ & Selective admissions. \\
\hline Fenway High School & $\mathrm{x}$ & $\mathrm{x}$ & $9-12$ & Selective admissions. \\
\hline Josiah Quincy Upper School & $\mathrm{x}$ & $\mathrm{x}$ & $6-12$ & All students guaranteed admission. \\
\hline New Mission High School & $\mathrm{x}$ & $\mathrm{x}$ & $9-12$ & Selective admissions. \\
\hline TechBoston Academy & 2003-2006 & $\mathrm{x}$ & $9-12$ & No Grade 9 class in 2002 (new school). \\
\hline
\end{tabular}

Notes: Schools are excluded from the lottery study (those marked with $\mathrm{x}$ in column (1)) if they are undersubscribed, only have seats for students with guaranteed admissions, did not keep sufficient records, or if they do not have an entry lottery at the school level start grade as indicated in the notes. Fredrick Douglass Charter School and Roxbury Charter High Public School were closed by the State Board of Education in the 2004-2005 school year. A school that spans K-8 is listed as both elementary and middle. $K-8$ pilot start grade as indicated in the notes. Fredrick Douglass Charter Schoo
schools contribute to both the elementary and middle school samples. 


\begin{tabular}{|c|c|c|c|c|}
\hline & $\begin{array}{l}\text { Elementary } \\
\text { (1) }\end{array}$ & \multicolumn{2}{|c|}{$\begin{array}{l}\text { Middle School } \\
\text { (2) }\end{array}$} & $\begin{array}{l}\text { High School } \\
\text { (3) }\end{array}$ \\
\hline \multicolumn{5}{|c|}{ A. Charter Lottery Sample } \\
\hline Application cohorts & - & \multicolumn{2}{|c|}{$2002-2007$} & $2002-2006$ \\
\hline Applications to charter & - & \multicolumn{2}{|c|}{3,940} & 4,726 \\
\hline Excluding applications not matched to state dataset & - & \multicolumn{2}{|c|}{3,816} & 4,425 \\
\hline Excluding applications with sibling priority & - & \multicolumn{2}{|c|}{3,593} & 4,309 \\
\hline $\begin{array}{l}\text { Excluding applications that applied to a charter not subject to } \\
\text { randomization }\end{array}$ & - & \multicolumn{2}{|c|}{2,768} & 4,067 \\
\hline Transforming applications into one observation per student & - & \multicolumn{2}{|c|}{2,275} & 3,028 \\
\hline Excluding students with no follow-up test score & - & \multicolumn{2}{|c|}{2,020} & 2,418 \\
\hline $\begin{array}{l}\text { Excluding students not in BPS or in a charter school in Boston at } \\
\text { baseline (this also drops those without baseline demographics) }\end{array}$ & - & \multicolumn{2}{|c|}{1,355} & 1,957 \\
\hline Excluding students with no baseline test scores & - & \multicolumn{2}{|c|}{1,331} & 1,934 \\
\hline $\begin{array}{l}\text { Number of follow-up LEA scores for students in BPS or a Boston } \\
\text { charter at baseline }\end{array}$ & - & \multicolumn{2}{|c|}{2,416} & 1,947 \\
\hline $\begin{array}{l}\text { Number of follow-up Math scores for students in BPS or a Boston } \\
\text { charter at baseline }\end{array}$ & - & \multicolumn{2}{|c|}{2,582} & 1,929 \\
\hline \multicolumn{5}{|c|}{ B. Pilot Lottery Sample } \\
\hline & & $\begin{array}{l}\text { 6th grade } \\
\text { applicants }\end{array}$ & $\begin{array}{c}\text { K2 } \\
\text { applicants }\end{array}$ & \\
\hline Application cohorts & $2002-2004$ & 2002-2007 & $1997-2001$ & 2003-2006 \\
\hline Applied to pilot school as first choice & 1,259 & 4,865 & 1,273 & 1,422 \\
\hline Excluding guarantees and students with sibling priority & 1,051 & 3,545 & 1,007 & 1,391 \\
\hline Excluding students that applied to a pilot not subject to randomization & 934 & 1,722 & 752 & 1,391 \\
\hline Excluding students with no follow-up test score & 700 & 1,588 & 444 & 1,067 \\
\hline $\begin{array}{l}\text { Excluding students not in BPS or in a charter school in Boston at } \\
\text { baseline (this also drops those without baseline demographics }\end{array}$ & 573 & 1,474 & 443 & 1,010 \\
\hline Excluding students with no baseline test scores & - & 1,298 & - & 1,003 \\
\hline $\begin{array}{l}\text { Number of follow-up ELA scores for students in BPS or a Boston } \\
\text { charter at baseline }\end{array}$ & 876 & 2,645 & 745 & 1,007 \\
\hline $\begin{array}{l}\text { Number of follow-up Math scores for students in BPS or a Boston } \\
\text { charter at baseline }\end{array}$ & 874 & 3,075 & 776 & 996 \\
\hline \multicolumn{5}{|c|}{ C. Regression Sample } \\
\hline Baseline years & $2002-2005$ & \multicolumn{2}{|c|}{ 2002-2006 } & $2002-2006$ \\
\hline $\begin{array}{l}\text { Students in BPS or in a charter school in Boston and demographics at } \\
\text { baseline }\end{array}$ & 17,293 & \multicolumn{2}{|c|}{23,976} & 25,588 \\
\hline $\begin{array}{l}\text { Students in BPS or in a charter school in Boston and demographics at } \\
\text { outcome }\end{array}$ & 12,552 & \multicolumn{2}{|c|}{20,105} & 18,925 \\
\hline Excluding students with no follow-up test score & 12,093 & \multicolumn{2}{|c|}{19,187} & 16,703 \\
\hline Excluding students with no baseline test scores & - & \multicolumn{2}{|c|}{18,584} & 16,200 \\
\hline $\begin{array}{l}\text { Number of follow-up test scores for students in BPS or a Boston } \\
\text { charter at baseline and outcome }\end{array}$ & 20,058 & \multicolumn{2}{|c|}{34,301} & 16,609 \\
\hline $\begin{array}{l}\text { Number of follow-up test scores for students in BPS or a Boston } \\
\text { charter at baseline and outcome }\end{array}$ & 17,356 & \multicolumn{2}{|c|}{38,583} & 16,350 \\
\hline
\end{tabular}


Table A.3: Differential Attrition Omitting Unbalanced Cohorts

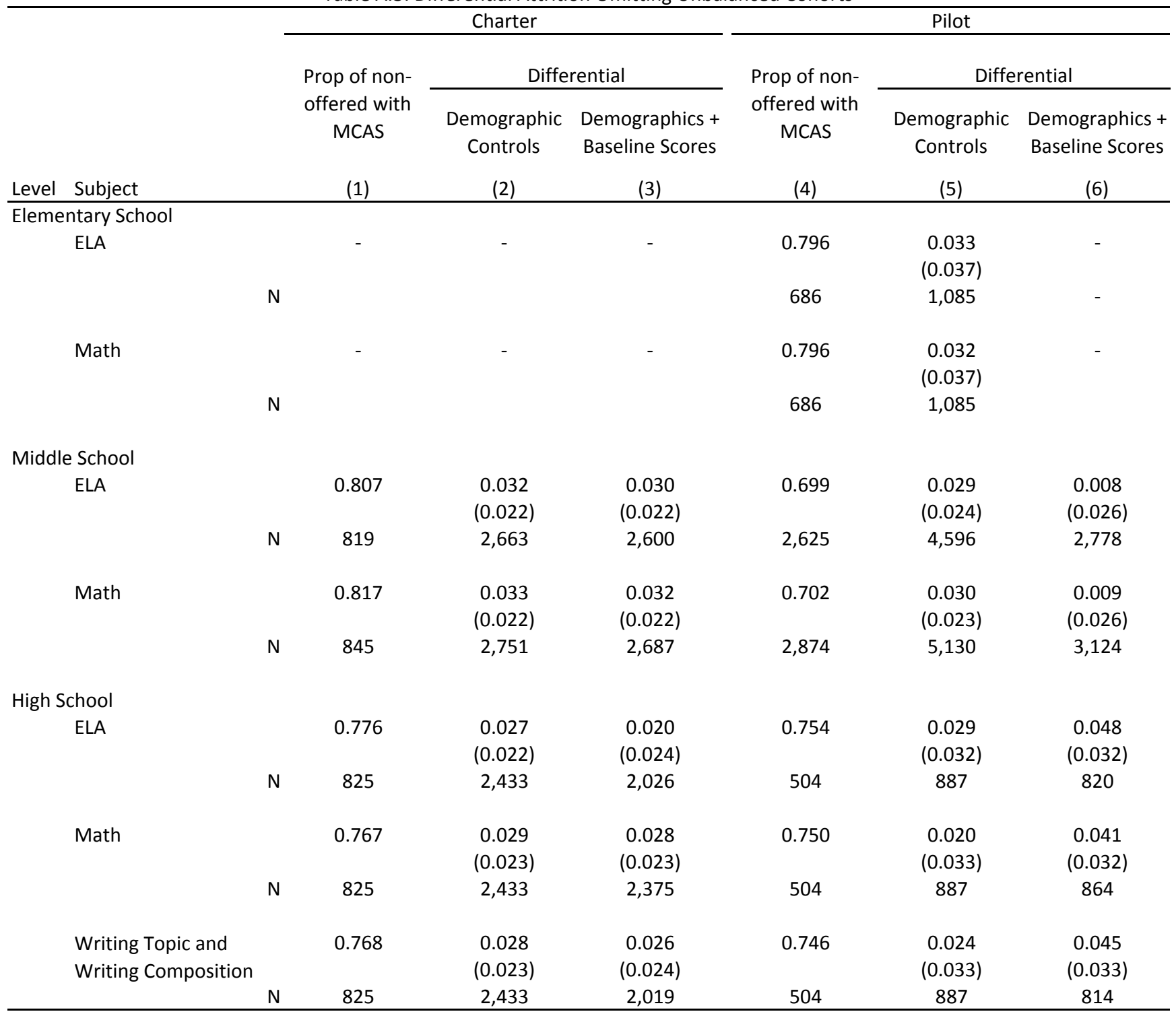

Notes: This table has the same notes as Table 6, but uses samples that excludes the following cohorts: Charter 6th grade ELA (2005 5th grade applicants), Charter 7th grade ELA (2004 6th grade applicants), Charter 6th grade Math (2005 5th grade applicants and 2002 5th grade applicants), Charter 7th grade Math (2004 6th grade applicants), Pilot 10th grade ELA (2006 high school applicants), Pilot 10th grade Math (2006 high school applicants), Pilot 10 th grade writing (2006 high school applicants). Standard errors, in parentheses, are clustered as described in the Table 4 notes. 
Table A.4: Charter and Pilot Lottery Results Omitting Unbalanced Cohorts

\begin{tabular}{|c|c|c|c|c|c|c|c|c|c|c|}
\hline \multirow{2}{*}{$\begin{array}{l}\text { Level } \\
\end{array}$} & \multirow[b]{2}{*}{ Subject } & \multicolumn{5}{|c|}{ Charter } & \multicolumn{4}{|c|}{ Pilots } \\
\hline & & & $\begin{array}{c}\text { First Stage } \\
\text { (1) }\end{array}$ & $\begin{array}{l}\text { Reduced Form } \\
\text { (2) }\end{array}$ & $\begin{array}{c}2 S L S \\
(3)\end{array}$ & $\begin{array}{c}2 \text { SLS w/demos } \\
\text { (4) }\end{array}$ & $\begin{array}{c}\text { First Stage } \\
(5)\end{array}$ & $\begin{array}{l}\text { Reduced Form } \\
\text { (6) }\end{array}$ & $\begin{array}{c}2 S L S \\
(7)\end{array}$ & $\begin{array}{c}2 S L S \text { w/demos } \\
\text { (8) }\end{array}$ \\
\hline \multicolumn{11}{|c|}{ Elementary School } \\
\hline \multirow{2}{*}{\multicolumn{2}{|c|}{ ELA }} & & - & - & - & - & $\begin{array}{c}2.852^{* * *} \\
(0.193)\end{array}$ & $\begin{array}{l}0.196 * * \\
(0.078)\end{array}$ & $\begin{array}{c}0.069 * * \\
(0.027)\end{array}$ & $\begin{array}{c}0.064^{* * *} \\
(0.024)\end{array}$ \\
\hline & & $\mathrm{N}$ & & & & & & 876 & & 876 \\
\hline \multirow{2}{*}{\multicolumn{2}{|c|}{ Math }} & & - & - & - & - & $\begin{array}{c}2.858^{* * *} \\
(0.194)\end{array}$ & $\begin{array}{c}0.177^{* *} \\
(0.078)\end{array}$ & $\begin{array}{c}0.062^{* *} \\
(0.027)\end{array}$ & $\begin{array}{c}0.060^{* *} \\
(0.026)\end{array}$ \\
\hline & & $N$ & & & & & & 874 & & 874 \\
\hline \multicolumn{11}{|c|}{ Middle School } \\
\hline \multirow{2}{*}{\multicolumn{2}{|c|}{ ELA }} & & $\begin{array}{c}0.950 * * * \\
(0.122)\end{array}$ & $\begin{array}{c}0.171^{* * *} \\
(0.064)\end{array}$ & $\begin{array}{c}0.179 * * * \\
(0.066)\end{array}$ & $\begin{array}{c}0.147^{* * *} \\
(0.056)\end{array}$ & $\begin{array}{c}1.385^{* * *} \\
(0.190)\end{array}$ & $\begin{array}{c}0.023 \\
(0.065)\end{array}$ & $\begin{array}{c}0.017 \\
(0.047)\end{array}$ & $\begin{array}{c}0.007 \\
(0.043)\end{array}$ \\
\hline & & $\mathrm{N}$ & & 2,238 & & 2,238 & & 3,364 & & 3,364 \\
\hline \multirow{2}{*}{\multicolumn{2}{|c|}{ Math }} & & $\begin{array}{c}0.906^{* * *} \\
(0.115)\end{array}$ & $\begin{array}{c}0.389 * * * \\
(0.071)\end{array}$ & $\begin{array}{c}0.429 * * * \\
(0.080)\end{array}$ & $\begin{array}{c}0.408^{* * *} \\
(0.070)\end{array}$ & $\begin{array}{c}1.291^{* * *} \\
(0.182)\end{array}$ & $\begin{array}{l}-0.078 \\
(0.069)\end{array}$ & $\begin{array}{l}-0.061 \\
(0.053)\end{array}$ & $\begin{array}{l}-0.057 \\
(0.048)\end{array}$ \\
\hline & & $\mathrm{N}$ & & 2,340 & & 2,340 & & 3,825 & & 3,825 \\
\hline \multicolumn{11}{|c|}{ High School } \\
\hline \multirow{2}{*}{\multicolumn{2}{|c|}{ ELA }} & & $\begin{array}{c}0.724 * * * \\
(0.131)\end{array}$ & $\begin{array}{c}0.148 * * * \\
(0.053)\end{array}$ & $\begin{array}{c}0.204^{* * *} \\
(0.066)\end{array}$ & $\begin{array}{c}0.197^{* * *} \\
(0.058)\end{array}$ & $\begin{array}{c}0.591 * * * \\
(0.101)\end{array}$ & $\begin{array}{c}0.020 \\
(0.053)\end{array}$ & $\begin{array}{c}0.034 \\
(0.087)\end{array}$ & $\begin{array}{c}0.023 \\
(0.091)\end{array}$ \\
\hline & & $\mathrm{N}$ & & 1,839 & & 1,839 & & 686 & & 686 \\
\hline \multirow{2}{*}{\multicolumn{2}{|c|}{ Math }} & & $\begin{array}{c}0.718^{* * *} \\
(0.129)\end{array}$ & $\begin{array}{c}0.233 * * * \\
(0.061)\end{array}$ & $\begin{array}{c}0.324^{* * *} \\
(0.080)\end{array}$ & $\begin{array}{c}0.282^{* * *} \\
(0.075)\end{array}$ & $\begin{array}{c}0.577^{* * *} \\
(0.101)\end{array}$ & $\begin{array}{l}-0.062 \\
(0.075)\end{array}$ & $\begin{array}{l}-0.107 \\
(0.127)\end{array}$ & $\begin{array}{l}-0.149 \\
(0.127)\end{array}$ \\
\hline & & $\mathrm{N}$ & & 1,823 & & 1,823 & & 681 & & 681 \\
\hline \multirow{2}{*}{\multicolumn{2}{|c|}{ Writing Topic }} & & $\begin{array}{c}0.722 * * * \\
(0.130)\end{array}$ & $\begin{array}{c}0.185 * * * \\
(0.066)\end{array}$ & $\begin{array}{c}0.256^{* * *} \\
(0.086)\end{array}$ & $\begin{array}{c}0.248 * * * \\
(0.081)\end{array}$ & $\begin{array}{c}0.582 * * * \\
(0.102)\end{array}$ & $\begin{array}{c}0.091 \\
(0.073)\end{array}$ & $\begin{array}{c}0.156 \\
(0.121)\end{array}$ & $\begin{array}{c}0.146 \\
(0.130)\end{array}$ \\
\hline & & $\mathrm{N}$ & & 1,823 & & 1,823 & & 678 & & 678 \\
\hline & Writing & & $0.722 * * *$ & $0.121 * *$ & $0.167^{* *}$ & $0.167^{* *}$ & $0.582 * * *$ & 0.058 & 0.099 & 0.092 \\
\hline & Composition & $\mathrm{N}$ & $(0.130)$ & $\begin{array}{c}(0.053) \\
1,823 \\
\end{array}$ & $(0.069)$ & $\begin{array}{c}(0.066) \\
1,823 \\
\end{array}$ & $(0.102)$ & $\begin{array}{c}(0.065) \\
678 \\
\end{array}$ & $(0.107)$ & $\begin{array}{c}(0.118) \\
678 \\
\end{array}$ \\
\hline
\end{tabular}

Notes: This table repeats the analysis of Table 4, using the balanced-cohorts sample studied in Table A3. The sample is restricted to students with baseline demographic characteristics and excludes the following cohorts: Charter 6th grade ELA (2005 5th grade applicants), Charter 7th grade ELA (2004 6th grade applicants), Charter 6th grade Math (2005 5th grade applicants and 20025 th grade applicants), Charter 7th grade Math (2004 6th grade applicants), Pilot 10th grade ELA (2006 high school applicants), Pilot 10th grade Math (2006 high school applicants), Pilot 10 th grade writing (2006 high school applicants). Standard errors, in parentheses, are clustered as described in the Table 4 notes.

${ }^{*}$ significant at $10 \%$; ${ }^{* *}$ significant at $5 \%$; $* * *$ significant at $1 \%$ 


\section{References}

[1] Abadie, A. (2002). "Bootstrap Tests for Distributional Treatment Effects in Instrumental Variable Models." Journal of the American Statistical Association, 97(457): 284-292.

[2] Abadie, A. (2003). "Semiparametric Instrumental Variable Estimation of Treatment Response Models." Journal of Econometrics, 113(2): 231-263.

[3] Abdulkadiroğlu, A. and Sönmez, T. (2003). "School Choice: A Mechanism Design Approach." American Economic Review, 93(3): 729-747.

[4] Abdulkadiroğlu, A. Pathak, P. A., Roth A. E. and Sönmez, T. (2006). "Changing the Boston School Choice Mechanism.” NBER Working Paper 11965.

[5] Abdulkadiroğlu, A, Pathak, P. A., and Roth, A. E. (2009). "Strategyproofness versus Efficiency in Matching with Indifferences: Redesigning the NYC High School Match." American Economic Review, 99(5), forthcoming.

[6] Angrist, J. (1991). "Group-data Estimation and Testing in Simple Labor Supply Models." Journal of Econometrics, 47(2-3): 243-266.

[7] Angrist, J. (1997). "Conditional Independence in Sample Selection Models." Economics Letters, 54(2): 103-112.

[8] Angrist, J., Bettinger, E., Bloom, E., King, E. and Kremer, M. (2002). "Vouchers for Private Schooling in Columbia: Evidence from a Randomized Natural Experiment." American Economic Review, 92(5): 1535-1558.

[9] Angrist, J., Imbens, G., and Rubin, D. (1996). "Identification of Causal Effects Using Instrumental Variables." JASA Applications invited paper, with comments and authors' rejoinder, Journal of the American Statistical Association, 91 (434): 444-472.

[10] Angrist, J. and Pischke, J.S. (2009). Mostly Harmless Econometrics: An Empiricist's Companion, Princeton University Press.

[11] Berends, M., Mendiburo, M. and Nicotera, A. (2008). "Charter Schools Effects in an Urban School District: An Analysis of Student Achievement Growth," Working Paper, Vanderbilt University

[12] Bettinger, E. (2005). "The Effect of Charter Schools on Charter Students and Public Schools." Economics of Education Review, 24(2): 133-147. 
[13] Bifulco, R. and Ladd, H. (2006). "The Impact of Charter Schools on Student Achievement: Evidence from North Carolina." American Education Finance Association, 1(1): 50-90.

[14] Booker, K., Gilpatric, S. M., Gronberg, T., and Jansen, D. (2007). "The Effect of Charter Schools on Traditional Public School Students in Texas: Are Children Who Stay Behind Left Behind?" Journal of Urban Economics, 64(1): 123-145.

[15] Booker, K.,T.R. Sass, B. Gill, and R. Zimmer (2008). "Going Beyond Test Scores: Evaluating Charter School Impact on Educational Attainment in Chicago and Florida," RAND Working Paper WR-610-BMG, August.

[16] Center for Collaborative Education (2006). "Description of the Boston Pilot Schools Network." Accessed November 25, 2009 at http://www.ccebos.org/pilotschools/pilot_qa.doc.

[17] Clark, D. (2009). "The Performance and Competitive Effect of School Autonomy." Journal of Political Economy, 117(4): 745-783.

[18] CREDO. (2009). Multiple Choice: Charter Performance in 16 states. Stanford University: Center for Research on Education Outcomes.

[19] Cullen, J. B., Jacob, B. A. and Levitt, S. (2006). "The Effect of School Choice on Participants: Evidence from Randomized Lotteries." Econometrica, 74(5): 1191-1230.

[20] Deming, D. (2009). "Better Schools, Less Crime?" Unpublished working paper, Harvard University.

[21] Dobbie, W. and Fryer, R. (2009). "Are High Quality Schools Enough to Close the Achievement Gap? Evidence from a Social Experiment in Harlem.” NBER Working Paper 15473.

[22] Eberts, R. W. and Hollenbeck, K. (2002). Impact of Charter School Attendance on Student Achievement in Michigan. Upjohn Institute Staff Working Paper No. 02-080

[23] Hanushek E. A., Kain, J. F., Rivkin, S. G., and Branch, G. F. (2007). "Charter School Quality and Parental Decision Making with School Choice." Journal of Public Economics, 91(5-6): 823-48.

[24] Hastings, J., Kane, T., and Staiger, D. (2008). "Heterogeneous Preferences and the Efficacy of Public School Choice." NBER Working Paper 2145 and Working Paper 11805 combined.

[25] Hoxby, C. M. (2000). "Does Competition Among Public Schools Benefit Students and Taxpayers?" American Economic Review, 90(5): 1209-1238. 
[26] Hoxby, C. M. (2007). "Does Competition Among Public Schools Benefit Students and Taxpayers? Reply." American Economic Review, 97(5): 2038-2055.

[27] Hoxby, C. M. and Murarka, S. (2009). "Charter Schools in New York City: Who Enrolls and How They Affect Student Achievement." NBER Working Paper 14852.

[28] Hoxby, C. M., Murarka, S., and Kang, J. (2009). How New York City's Charter Schools Affect Achievement, August 2009 report. Second report in series. Cambridge, MA: New York City Charter Schools Evaluation Project.

[29] Hoxby, C. M. and Rockoff, J. (2005). "The Impact of Charter Schools on Student Achievement." Harvard Institute of Economic Research Working Paper Series.

[30] Imbens, G. and Angrist, J. (1994). "Identification and Estimation of Local Average Treatment Effects." Econometrica, 62(2): 467-475.

[31] Jacob, B. and Lefgren, L. (2007). "What Do Parents Value in Education? An Empirical Investigation of Parents' Revealed Preferences for Teachers." Quarterly Journal of Economics, 122(4): 1603-1637.

[32] Manzo, K. K. (2007). "Arts Education Building Steam in L.A. Area Schools." Education Week, 02774232, 26(41), 6/13.

[33] Massachusetts Department of Elementary and Secondary Education. (2009a). Massachusetts Charter Schools Fact Sheet. Retrieved online on September 30, 2009 from: http://www.doe.mass.edu/charter/factsheet.pdf.

[34] Massachusetts Department of Elementary and Secondary Education. (2009b). 20082009 Enrollment by Grade Report. Retrieved online on September 30, 2009 from: http://profiles.doe.mass.edu/state_report/enrollmentbygrade.aspx?mode=school\&orderBy=.

[35] Matthews, J. (2009). Work Hard. Be Nice. How Two Inspired Teachers Created the Most Promising Schools in America. Chapel Hill: Alongquin Press.

[36] Merseth, K., Robert, J., Cooper, K., Casey, M. C., and Valant, J. (2009). Inside Urban Charter Schools: Promising Practices and Strategies in Five High-performing Charter Schools. Cambridge: Harvard Education Publishing.

[37] National Alliance for Public Charter Schools. (2009). Public Charter School Dashboard. Washington D.C. Retrieved on September 21, 2009 from: http://www.publiccharters.org/files/publications/DataDashboard.pdf. 
[38] Rothstein, J. (2006). "Good Principals or Good Peers? Parental Valuations of School Characteristics, Tiebout Equilibrium, and the Incentive Effects of Competition among Jurisdictions." American Economic Review, 96(4): 1333-1350.

[39] Rothstein, Jesse. (2007). "Does Competition Among Public Schools Benefit Students and Taxpayers? Comment on Hoxby (2000)." American Economic Review, 97(5): 2026-2037.

[40] Rothstein, R. (2004). Class and Schools: Using Social, Economic, and Educational Reform to Close the Black-White Achievement Gap. Columbia: Teachers College Press.

[41] Rouse, C. (1998). "Private School Vouchers and Student Achievement: An Evaluation of the Milwaukee Parental Choice Program." Quarterly Journal of Economics, 113(2): 553-602.

[42] Thernstrom, A. and Thernstrom, S. (2003). No Excuses: Closing the Racial Gap in Learning. New York: Simon \& Schuster.

[43] Vaznis, J. (2009). "Backers Seek End to Charter Cap." The Boston Globe, August 5.

[44] Wilson, S. F. (2008). "Success at Scale in Charter Schooling." Working Paper 2008-02 from the American Enterprise Institute Future of American Education Project. 